\title{
Does the United States Have a Productivity Slowdown or a Measurement Problem?
}

\author{
David M. Byrne \\ Federal Reserve Board \\ John G. Fernald \\ Federal Reserve Bank of San Francisco \\ Marshall B. Reinsdorf \\ International Monetary Fund
}

April 2016

Working Paper 2016-03

http://www.frbsf.org/economic-research/publications/working-papers/wp2016-03.pdf

\section{Suggested citation:}

Byrne, David M., Marshall B. Reinsdorf, John G. Fernald. 2016. "Does the United States have a Productivity Slowdown or a Measurement Problem?” Federal Reserve Bank of San Francisco Working Paper 2016-03. http://www.frbsf.org/economic-research/publications/workingpapers/wp2016-03.pdf

The views in this paper are solely the responsibility of the authors and should not be interpreted as reflecting the views of the Federal Reserve Bank of San Francisco, the Board of Governors of the Federal Reserve System, or the International Monetary Fund. 


\title{
Does the United States have a Productivity Slowdown or a Measurement Problem?
}

\author{
David M. Byrne, John G. Fernald, and Marshall B. Reinsdorf*
}

April 20, 2016

\begin{abstract}
After 2004, measured growth in labor productivity and total factor productivity (TFP) slowed. We find little evidence that the slowdown arises from growing mismeasurement of the gains from innovation in information-technology (IT)-related goods and services. First, mismeasurement of IT hardware is significant prior to the slowdown and because the domestic production of these products has fallen, the quantitative effect on productivity is larger in the 1995-2004 period than since, despite mismeasurement worsening for some types of IT. Hence, our adjustments make the slowdown in labor productivity worse. The effect on TFP is more muted. Second, many of the tremendous consumer benefits from smartphones, Google searches, and Facebook are, conceptually, non-market: Consumers are more productive in using their nonmarket time to produce services they value. These benefits raise consumer well-being but do not imply that market-sector production functions are shifting out more rapidly than measured. Moreover, estimated gains in non-market production are too small to compensate for the loss in overall well-being from slower market-sector productivity growth. In addition to IT, other measurement issues we can quantify (such as increasing globalization and fracking) are also quantitatively small relative to the slowdown.

* Byrne, Fernald and Reinsdorf are at the Federal Reserve Board (david.m.byrne@frb.gov), the Federal Reserve Bank of San Francisco (fernaldjg@gmail.com), and the International Monetary Fund (mreinsdorf@imf.org), respectively. We thank Martin Baily, Erik Brynjolfsson, Erwin Diewert, Carol Corrado, Jean Flemming, Bob Gordon, Pete Klenow, Jim Stock, and Hal Varian for helpful comments and conversations. We thank Travis Adams, Genevieve Denoeux, and Arthi Rabbane for excellent research assistance. The title refers to a phrase in a Wall Street Journal article by Aeppel (2015). The views expressed in this paper are those of the authors and should not be attributed to the IMF or its managers or Executive Directors, the Federal Reserve Bank of San Francisco, the Board of Governors, or the Federal Reserve System.
\end{abstract}


"The things at which Google and its peers excel, from Internet search to mobile software, are changing how we work, play and communicate, yet have had little discernible macroeconomic impact.... Transformative innovation really is happening on the Internet. It's just not happening elsewhere.”

Greg Ip, Wall Street Journal, August 12, 2015

U.S. productivity data highlight the paradox at the heart of the quotation above. The fast pace of innovation related to information technology (IT) seems intuitive and obvious. Yet productivity growth has been modest, at best, since the early 2000s. We examine the hypothesis that the U.S. economy has a growing measurement problem rather than a productivity slowdown (e.g., Aeppel, 2015, Feldstein, 2015, and Hatzius and Dawsey, 2015). Some components of real output, including the services provided by information technology, are indeed poorly measured. Yet for mismeasurement to explain the productivity slowdown, growth must be mismeasured by more than in the past. While we find considerable evidence of mismeasurement, we find no evidence that the biases have gotten worse since the early 2000s.

We focus especially on IT-related hardware and software, where mismeasurement is sizeable, as well as e-commerce and "free” digital services such as Facebook and Google. More broadly, we identify potential biases to productivity from intangible investment, globalization, and technical innovations in oil and gas production (i.e., fracking). These are all areas where it is plausible that measurement has worsened since the early 2000s. But taken together, our adjustments turn out to make the post-2004 slowdown in labor productivity even larger than measured. The slowdown of business-sector total factor productivity (TFP) growth is only modestly affected.

Figure 1 summarizes our quantitative analysis. The dark portions of the bars show the published data on average growth in U.S. business-sector labor productivity, or output per hour. Growth was exceptional from 1995 through 2004, but the pace then slowed by more than 1-3/4 
percent per year. (Section 1 and an appendix discuss data, the timing of the bars in the chart, and the similar pattern in measures of TFP). Suppose productivity growth had continued at its 19952004 pace of 3-1/4 percent per year. Then, holding hours growth unchanged, business-sector GDP would be \$3 trillion (24 percent) larger by 2015 in inflation-adjusted 2009 dollars. $^{1}$

We find no evidence that growing mismeasurement related to IT or other factors can fill this gap. In Section 1, we explore the hypothesis that the slowdown reflects the growing importance of poorly measured industries with low productivity growth, such as health care and other services. These industries are indeed growing as a share of the economy but holding weights fixed at their 1987 values would make little difference to the slowdown. That most industries show slowing growth matters more than changing weights.

We then turn to biases within specific sectors. Figure 1 shows our adjustments for various biases. We incorporate consistent measurement of quality-adjusted prices for computers and communications equipment; judgmental corrections to prices of specialized informationprocessing equipment and software; a broader measure of intangible investment than is used in the national accounts; and ballpark adjustments for other issues-Internet access, e-commerce, globalization, and fracking. These adjustments make labor productivity growth since 2004 look better. But the adjustments to account for mismeasurement matter even more in the 1995-2004 period. On balance, therefore, the labor productivity slowdown becomes modestly larger. ${ }^{2}$

In particular, although we find somewhat more mismeasurement of computer and communications equipment prices in the recent period than previously, domestic production of those products has plunged, making this mismeasurement less important for GDP. Although Byrne et al. (2015) show that microprocessor (MPU) price declines are substantially understated,

\footnotetext{
${ }^{1}$ In independent work, Syverson (2016) suggests a similar calculation of the missing growth.

2 There are also some sources of upward measurement error in growth related to globalization that have become less important. Still, we will usually take "mismeasured” to mean, “causing GDP growth to be understated.”
} 
this has little immediate implication for productivity; because MPUs are not final products, they only affect GDP through net trade, which is roughly in balance for semiconductors.

The “other” adjustments in Figure 1 include improved Internet quality (Section 3) and ecommerce (Section 4), which together add about 5 basis points (bp) more in the post-2004 period than from 1995-2004. This adjustment is small, reflecting the conceptual challenges involved with bringing more of the services of Google, Facebook, and the like into market-sector GDP. The major "cost” to consumers of these services is not broadband access, cell phone service, or the phone or computer; rather, it is the opportunity cost of time. That time cost is not consumption of market sector output. It is akin to the consumer surplus obtained from television (an old economy invention) or from playing soccer with ones’ children. Following Becker (1965), activities that combine market products (an iPhone, a TV, a soccer ball) with the consumer's own time are properly thought of as nonmarket production that uses market goods and services as inputs. As we discuss, a small amount of market output could conceivably be included in final consumption, corresponding to online ad spending. That spending is relatively modest and has little effect on growth in output or productivity. Thus, while the digital services are valuable to households, the possible mismeasurement in these areas makes essentially no difference to market-sector labor-productivity and TFP growth. ${ }^{3}$ That said, to the extent that the effect of innovation on the quality of leisure is outpacing the effect on market activities, market productivity growth might have become a less reliable measure of overall welfare.

These other adjustments also include effects from globalization and fracking (Section 5). Globalization was most intense in the late 1990s and early 2000s. That caused real import growth to be understated and, correspondingly, artificially boosted measured GDP growth by about

\footnotetext{
${ }^{3}$ Nordhaus (2006) sketches principles of national accounting for non-market as well as market goods and services.
} 
$1 / 10^{\text {th }}$ percentage point (10 bp) per year from 1995 to 2004 . Hence, the “other” bar contributes negatively in 1995-2004 in Figure 1. Fracking, on the other side, boosts productivity growth by about 5 bp after 2004. Together, these adjustments shave about $1 / 10^{\text {th }}$ percentage point from growth in the $1995-2004$ period, and add about $1 / 10^{\text {th }}$ to growth thereafter.

For TFP, the adjustments are even smaller than for labor productivity. Adjusting equipment, software, and intangibles implies faster GDP growth, but also faster input growth (since effective capital services rise more quickly). After adjusting hardware and software, the aggregate TFP slowdown after 2004 is modestly worse. Adding a broader measure of intangibles, as in Corrado et al. (2009), works modestly in the other direction, so our broadest adjustment for investment goods leaves the 1-1/4 percentage point slowdown in TFP a few basis points worse. The other (non-investment-good) adjustments we make pass directly into TFP but, on balance, they still leave the slowdown in TFP only modestly attenuated.

In making these points, we draw on a large body of existing research. Before presuming that the measurement problems have gotten worse, it is worth remembering that in the 1990s and early 2000s, a lot of work looked at missing quality improvement, the problem of new goods, and the fact that consumers had an explosion of new varieties. The biases were frequently estimated to be large. For example, VCRs, cell phones, and other products were added to the consumer price index (CPI) a decade or so after they appeared, and when their prices had already fallen by 80 percent or so (Gordon, 2015; Hausman, 1999). The explosion in consumer choice, and the possibilities for so-called mass customization, were documented in the 1990s. Around the same time, the Boskin Commission estimated that omitted quality change in new goods was worth at least $1 \frac{1}{2}$ percent per year (Boskin et al., 1998). (Some academic research found even larger effects e.g., Bils and Klenow, 2000, while the National Academy of Science Committee 
on National Statistics panel report, 2002, argued for a smaller number.) So again, the issue is not whether there is bias. The question is whether it is larger than it used to be.

The structure of the paper is as follows. Section 1 lays out motivating facts about the productivity slowdown, including a discussion of the changing industry composition of the U.S. economy. Section 2 discusses improved deflators for information technology and intangibles, and reworks the growth accounting with alternative capital deflators. We then turn to other issues in Sections 3 through 5 that plausibly changed after 2004. Section 6 concludes.

\section{The recent rise and fall of U.S. productivity growth}

Three productivity facts frame our subsequent discussion. First, as measured, growth in business-sector labor productivity and TFP rise sharply in the mid-1990s but then slow again after 2004 or so. Second, the slowdown is broadbased across industries, including in relatively well-measured ones, such as wholesale and retail trade, manufacturing, and utilities. Third, the TFP slowdown is not caused by the rising share of slow-productivity-growth industries.

Fernald (2014b) interprets the slowdown as a "return to normal” following a period of exceptional, broadbased gains from the production and use of information technology. The remaining sections of the paper explore rising mismeasurement as an alternative explanation. ${ }^{4}$

We focus now on TFP, which is defined as a residual: output growth not "explained” (in a proximate sense) by growth in inputs of capital and labor. In the longer run, TFP growth mainly reflects innovation in a broad sense. The appendix shows that changes in TFP growth have been the proximate driver of changes in labor-productivity growth, as theory would

\footnotetext{
4 A separate debate is whether the productivity slowdown of the 1970s was itself due to mismeasurement. Griliches (1994) points out that the post-1973 slowdown was concentrated in poorly measured industries. Gordon (2016, for example) argues instead that the post-1973 slowdown reflects the unusual strength of the 1920-1970 period rather than anything specific that happened in the 1970s. Relatedly, Fernald (1999) estimates that building the Interstate Highway System substantially boosted productivity growth in the 1950s and 1960s but then its effects ran their course. Triplett (1999) reviews arguments that the post-1973 slowdown was illusory.
} 
suggest. TFP as well as labor productivity slow sharply in the 2004-2007 period—prior to the Great Recession—relative to the late 1990s and early 2000s; the slowdown in growth is statistically significant in formal tests for a change in mean growth. ${ }^{5}$

Figure 2 shows the industry sources of the slowdown in business-sector TFP growth from a Bureau of Labor Statistics dataset. Because of data availability, the sub-periods shown are all between 1987 and 2013. We divide the private business economy into four mutually exclusive pieces: IT producing, wholesale and retail trade, “other well-measured,” and “poorly measured.”6 All sectors show somewhat slower growth after 2004, but the slowdown is particularly pronounced for wholesale and retail trade and the other relatively well-measured sectors. After 2000, IT production adds less and less to TFP growth, which we discuss in the next section. After 2004, wholesale and retail trade contribute negatively. This is noteworthy because IT provided a substantial boost to wholesale and retail trade in the preceding periods, in part through industry reorganization. Other (non-trade) well-measured industries contribute less after 2004. Thus, the slowdown is apparent even in areas such as trade and non-IT manufacturing, where measurement has traditionally been considered relatively good. (Of course, even in these industries unmeasured gains from quality improvements and new goods may be occurring.) Finally, “poorly measured” contributes negatively from 2004-2007 but then turns substantially positive from 2007-2013; quantitatively, the post-2007 shift reflects an increasingly positive contribution from finance and the elimination of a large negative contribution from construction.

\footnotetext{
${ }^{5}$ A possibly more "optimistic" perspective on recent developments comes from noting that TFP growth has continued since the Great Recession at its pre-1995 pace. That pace of TFP growth may be normal-it was, perhaps, the 1995-2003 period that was exceptional. Furthermore, in recent years TFP may be more relevant than labor productivity, whose weakness since 2010 partly reflects transitory factors associated with weak capital deepening. 6 “Other well measured” is most of manufacturing (except computers / electronic equipment), agriculture, mining, utilities, transportation, broadcasting, and accommodation. Nordhaus (2002) also considers wholesale and retail trade as well measured, but we have broken that out separately.
} 
The slowdown is also not simply a matter of weights that have been shifting towards poorly measured industries with low TFP growth, such as services. Services have been growing as a share of the economy and are inherently challenging to measure in real terms (Griliches, 1994; Triplett and Bosworth, 2004). Figure 3A compares actual TFP growth with a counterfactual where nominal industry value-added weights are held constant at their 1987 values. $^{7}$ Over the time periods shown, the growth rates of the two measures are within a few basis points. In other words, shifts in the industry composition of the economy play essentially no role in the productivity speedup in the mid-1990s or slowdown in the 2000s.

Why are the two series so similar? The value-added share of services and other relatively poorly measured industries rises about 10 percentage points from 1987 to 2013 . For the full sample, TFP growth in these poorly measured industries was about zero, compared with 2 percent annual growth for relatively well-measured industries (including IT hardware and trade). Hence, a back-of-the-envelope guess would be that, by the end of the sample, the fixed-weight index should grow about 20 bp faster, reflecting the 2 percentage point per year difference in growth times the 10 percentage point shift in weights. Roughly half the shift in weights had occurred by 1998, so the expected effect on the post-2000s slowdown might be 10 bp.

In Figure 3A, the differences are even smaller than that back-of-the-envelope calculation. First, within the groups of well-measured and poorly-measured industries, weights shifted towards faster-TFP-growth industries. These shifts partially offsets the broader shift towards services. Second, since 2007, “Baumol’s disease” has reversed-TFP growth in poorly measured services has been faster than in well-measured sectors.

\footnotetext{
${ }^{7}$ Value-added weighting of value-added TFP growth is essentially equivalent to doing so-called Domar weighting of gross-output residuals. The fixed weights are on nominal expenditures, not quantities. In the data, the rise in the nominal share of services reflects both faster growth in quantities as well as faster growth in prices.
} 
Panel B makes this point about weights a different way by showing that the slowdown after the early 2000s is broadbased across industries. The figure shows the change in average annual industry (value-added) TFP growth from 2004-2013 relative to 1995-2004. About twothirds of industries show a slowdown in measured TFP growth after 2004. We get a similar picture if we look at the change from 1995-2004 to 2004-2007, so it is not simply a matter of the Great Recession affecting many industries. We also get a similar picture using labor productivity, so it is not something about capital measurement.

Our results are consistent with some previous studies that have found that the shrinking size of well-measured sectors was not a first-order explanation for previous swings in productivity (Baily et al., 1988; Sichel, 1997).

Why did so many industries show a common slowdown after 2004? The economy plausibly received an exceptional boost from IT in the 1990s and early 2000s that hit many industries. But, by the mid-2000s, the "low-hanging fruit” of a wave of IT-based innovation (including associated reorganizations) had been plucked. For example, industries along the supply chain from factory to retailing were already substantially reorganized to reduce inventory, waste, and headcount; and IT-supported efficiencies in middle management and administrative support had been exploited. It is possible that latest waves of innovation will take time to bear fruit and that we are overlooking nascent IT-based productivity gains in service sectors such as health care and education. We sidestep this more challenging question and turn to an alternative hypothesis that rising mismeasurement might explain the patterns in the data. 


\section{Growing mismeasurement of information technology?}

In this section, we document longstanding challenges in measuring information processing equipment and software. ${ }^{8}$ Correcting for mismeasurement of these investment goods turns out to make the slowdown in labor productivity and TFP growth even worse after 2004. We also note a rise in uncertainty about these effects: Investment has shifted towards specialpurpose information processing equipment and intangibles, especially software, categories that have proven especially difficult to measure.

After moving roughly sideways in the post-war period through the late 1970s, the official information technology (IT) investment price index turned down as the PC era began, and then the rate of decline accelerated sharply to 6 percent per year on average during the "IT boom" and the early 2000s (table 1). Since 2004, the price declines have retreated to a modest rate of 1 percent, coinciding with the decrease in the contribution of IT production to TFP growth that was shown in Figure 2. This flattening out has led to a revival of interest in measurement of IT prices, and some recent studies find that official price statistics have substantially understated price declines in recent years. $^{9}$

Has worsening price mismeasurement caused a spurious slowdown in official estimates of output and real investment, distorting productivity estimates? Answering that question requires construction of a fully consistent time series. We employ price indexes developed by Byrne and Corrado (2016), who review the full post-war history of IT price research and construct alternative price indexes for IT investment and production using research not only for

\footnotetext{
${ }^{8}$ Our focus in this section is on the contribution of IT capital services to productivity and implications for TFP growth. Parallel measurement problems exist for IT consumer durables, which we do not discuss explicitly. However, we account for understatement of GDP from mismeasurement of IT through our adjustments to domestic production, whether for the consumer or business market.

${ }^{9}$ See research for communications equipment (Byrne and Corrado, 2015), computers (Byrne and Pinto, 2015; Byrne and Corrado, 2016), and microprocessors (Byrne, et al., 2015).
} 
recent years but also for earlier periods that may not have been incorporated into BEA's national income and product accounts (NIPAs).

We provide two alternative price indexes. The first, a “conservative” index, is based solely on research studies using detailed datasets on specific product classes. We extrapolate those results as described in Byrne and Corrado (2016) for communications equipment and for computers and peripherals. For the second, “liberal”, index, we add plausible assumptions about prices of IT products for which no direct studies are available, namely other information processing equipment and software. Overall, our alternative indexes suggest substantially faster price declines than shown in the NIPAs throughout the post-war period. For some categories (computers and communications equipment), price measurement appears to have worsened, but the importance of those categories in GDP has declined. On balance, the declining importance in GDP dominates, so the bias in GDP growth was larger in the past.

We discuss the component prices briefly here and compare them with the investment prices used in the NIPAs.

\subsubsection{Components of IT Investment}

\section{Computers and Peripherals}

The official investment price index for computers and peripherals reflects results of internal BEA research (Cole et al., 1986; Dulberger, 1989) which led to the adoption of hedonic regression techniques to account for the rapid technological advances embodied in new models of computers and peripherals. For the post-war period through the early 1980s, BEA prices are consistent with outside studies (Gordon, 1990; Triplett, 1990). Beginning in the 1990s, BLS adopted hedonics for computers (but not peripherals) as well and BEA now relies on BLS prices as inputs for the NIPA investment deflator (Grimm et al., 2005). Despite the commitment to 
quality-adjustment in the official statistics, outside research indexes indicate somewhat different price trends beginning in the 1980s. ${ }^{10}$

\section{Personal Computers}

Our alternative price index for computers and peripherals diverges from official prices beginning in 1984. For PCs, we adopt an aggregate of the indexes developed in a comprehensive study by Berndt and Rappaport (2001, 2003), which exhibits 8 percentage points faster declines through the early 2000s. The documentation for the BLS hedonic models is not comprehensive enough to allow us to identify the source of the difference in results with confidence.

More recently (since 2004), the BEA index for PCs has slowed dramatically and some aspects of the sources and methods used raise concerns about the accuracy of this development. Figure 5 (top panel) shows the average unit price of PCs sold in the U.S. business market reported by IDC Corp., which makes no adjustment for quality. The figure also shows the rate of change for the BEA investment price index for PCs. In the late 1990s and early 2000s, the gap between the two series indicates that quality improvements were contributing 15 to 20 percentage points to the fall in constant-quality PC prices. The gap has narrowed since that time and since 2010 the two series are almost identical, implying no improvement in PC quality, holding unit price constant, for the past five years.

Three measurement problems appear to contribute to this implausible result. First, the BEA investment series is the aggregate of a (domestic) production price index and an import price index calculated independently from one another with different source data (Figure 5). As a result, any discount accruing to a business switching from domestically-sourced to imported equipment is not reflected in the investment price index, a form of "outlet substitution bias” akin

\footnotetext{
${ }^{10}$ With appropriate data on characteristics, hedonic regressions are a useful tool for quality adjusting prices, but the absence of hedonic adjustment does not necessarily indicate a price index is biased. Other techniques may account for quality improvements as well. (Wasshausen and Moulten, 2006)
} 
to omitting from a consumption price index the price savings associated with switching to shopping at Walmart (Reinsdorf, 1993; Houseman et al., 2011).

Second, the price index for imports falls markedly slower than the index for domestic production over a prolonged period: a difference of 14 percentage points per year since its introduction in 1995. The implied continual rise in the relative price of imported computers is inconsistent with the increase in import penetration from 50 to 90 percent over the same period (Byrne and Pinto, 2015). This contradiction suggests that the price mismeasurement is more severe for import prices than for domestic producer prices. Among the possible contributing factors to the relatively flat import price series is the heavy presence of intrafirm (transfer) prices in the index (over 60 percent of the value of the basket in 2013). These prices may behave differently from arm's length prices. This may be related to the finding by Nakamura and Steinsson (2012) that a surprisingly high proportion of the items in the import price index sample never experience a price change prior to exiting the index basket. Also, new models are generally linked into the import price index in a way that would not capture any decline in quality adjusted price of the item (Kim and Reinsdorf, 2015).

This suggests the PPI would be a more appropriate deflator for investment, though the producer price index (PPI) itself has drawbacks. When quality-adjusting the computer PPIs, BLS controls primarily for technical features such as processor clock speed and features associated with changes in production costs. Design improvements not clearly tied to costs or not easily identified in technical specifications, such as circuits designed to work more effectively in parallel, may raise the value of the equipment to its user through superior performance without affecting the quality index. Thus, the approach used for quality adjustment in the PPI may lead to understatement of quality improvements and overstatement of inflation. 
Although we are aware of no research studying computer prices directly in recent periods, Byrne, et al. (2015) analyze prices for microprocessors (MPUs), the central analytical component of computers. When controls for direct measures of performance were used in hedonic analysis for MPUs (benchmark scores on a battery of user tasks), their hedonic price index fell over 20 percentage points faster than a hedonic index controlling for technical features over 2000-2013. We infer that the BLS hedonic may be understating the annual rate of quality improvement for PCs by 4 percentage points —-the (rounded) product of the bias in the MPU price index and the share of MPU inputs in the final value of PCs (15 percent). In our alternative index, we extend the Berndt-Rappaport index with the bias-adjusted PPI.

\section{Multi-user Computers}

The BLS price index for multi-user computers (computers other than PCs) used by BEA is quality-adjusted using a hedonic regression as well. Following the same logic used for PCs, we augment the BEA price index beginning in 1993 with an indicator of the average price per computer unit adjusted for MPU performance, which falls markedly faster than the PPI. The performance measure is an average of scores on a suite of benchmark tests developed by Systems Performance Evaluation Corporation (SPEC), a consortium of industry representatives, to provide reliable comparisons across systems. We blend this price-performance indicator with the PPI, which controls for computer features not accounted for by the SPEC benchmark. We employ a weighted average of the PPI and the price-performance trend to deflate multi-user computers. This alternative index falls 10 percentage points faster than the official BEA price.

\section{Storage Equipment}

For storage equipment as well, the PPI that is the basis for the BEA investment price index appears out of alignment with price-performance trends in the industry. From its introduction in 1993 to 2014, the PPI has fallen 12 percent per year on average, in stark contrast 
to the price per gigabyte for hard disk drives, currently the dominant technology in the industry, which fell 35 percent per year on average (McCallum, 2016). Recent research by Byrne (2015) employing detailed model-level prices for storage equipment developed prices that fell at nearly the rate of raw price-per-gigabyte series. We use the Byrne (2015) index extended backwards by the price-per-gigabyte series with a 4 percentage point bias adjustment. ${ }^{11}$

All told, our alternative index for computers and peripherals falls faster than the NIPA index beginning in the early 1980s, and the gap between the two increases markedly to 8 percentage points between 1995 and 2004. The difference between the indexes is even larger in recent years, an average of 12 percentage points (Figure 6, top panel). This substantial gap suggests additional work is needed to account well for computer investment in the NIPAs and the rising gap makes the issue increasingly important. But, the percentage point slowdown in the alternative index is still quite large and returns the rate of price declines to the pace seen prior to the 1990s IT boom.

\section{Communications Equipment}

Official investment prices for communications equipment reflect both BLS producer and import price indexes and internal BEA research (Grimm, 1996). Outside work, including price indexes published by the Federal Reserve Board, is incorporated to some extent as well, and the investment index does fall faster than the PPI for the industry (Figure 6, bottom panel). However, a substantial amount of research is not reflected in the NIPAs (Byrne and Corrado 2015, 2016). This includes work on transmission and switching equipment in the early post-war era by Flamm (1989), as consolidated and augmented by Gordon (1990), and satellite prices

\footnotetext{
${ }^{11}$ Research for the remaining category, peripherals, is sparse. The BEA investment price index fell 12 percent per year on average in the 1990s but 4 percent on average since then. Aizcorbe and Pho (2005) examine scanner data for eight categories of peripherals for 2001-2003. Although we note the geometric mean of price indexes for those categories falls 15 percent per year, we chose not to adjust the peripherals index based on this short time series.
} 
constructed by Byrne and Corrado (2015). For more recent years, the BEA investment price index appears inconsistent with new prices for cellular systems, data networking, and transmission developed in Byrne and Corrado (2015) and Doms (2000). Because sub-indexes are not published for communications equipment investment, it is impossible to analyze the sources of this difference. In any event, technological developments in the field that suggest careful attention is needed to account for quality change, such as fourth generation cellular systems now capable of delivering video.

Like the computer investment index, the Byrne and Corrado (2016) communications equipment investment index is carefully constructed to match the scope and weighting of the BEA index. All told, the difference between the BEA investment index and the alternative is noteworthy and the gap is slightly larger in the 2004-2014 period than in the 1995-2004 period. Unlike the index for computers and peripherals, the communications equipment index maintains roughly the same pace of decline as in the IT boom.

\section{Special-Purpose Electronics}

The remaining components of the BEA “other information processing” equipment category are a diverse group of special-purpose equipment designed for use in medical, military, aerospace, laboratory and industrial applications. ${ }^{12}$ Examples include magnetic resonance imaging (MRI) machines, electronic warfare countermeasure devices, and a wide variety of equipment used for monitoring and controlling industrial processes. Technological advances in recent years have been impressive. One well-known example is genomic sequencing, where

\footnotetext{
12 Navigational equipment and audio-visual equipment are classified as communications equipment in the BEA investment taxonomy.
} 
specialized equipment has contributed to dramatic efficiency gains: The cost of sequencing a human genome has dropped from roughly $\$ 1,000,000$ in 2008 to $\$ 1,000$ in $2015 .^{13}$

Surprisingly, with the exception of electro-medical equipment, which edges down modestly, the PPIs for these products have risen on average since the late 1990s. Differences in market structure (such as the smaller scale of production and the market power of military and medical customers) and the price trends of specialized inputs could cause prices for specialpurpose electronics to behave differently from prices for general-purpose electronics like computers (Byrne, 2015). Yet, these goods have electronic content comparable to computers, and one might expect the equipment prices to reflect the rapidly falling price of the electronic components used in their production. In our "liberal” alternative scenario, we remove roughly one-third of the difference between the trend price growth of special-purpose and of generalpurpose (computer and communications) electronics.

\section{Software}

Investment in software is deflated in the NIPAs by an aggregate of three sub-indexes: prepackaged, custom, and own-account software. BLS producer prices are available for prepackaged software and research has been conducted at BEA and by outside researchers into quality-adjusted price trends (Parker and Grimm, 2000; Copeland, 2013). To deflate investment in prepackaged software, BEA employs a BLS PPI with an adjustment reflecting the average difference between the PPI and their research results. Because direct observation of prices for custom and own-account software has not been possible, investment in these categories of

\footnotetext{
${ }^{13}$ Wittersrand (2016). While the sequencing of a human genome is not final output, improvements in the tools used to conduct science are the likely foundation of falling prices for health services in the future. Heather and Chain (2016) present the history of DNA sequencing equipment and note, “Over the years, innovations in sequencing protocols, molecular biology and automation increased the technological capabilities of sequencing while decreasing the cost, allowing the reading of DNA hundreds of basepairs in length, massively parallelized to produce gigabases of data in one run." See also Stein (2010) on the role of high-performance computing in genetics.
} 
software are deflated by a blend of an input cost index for the industry and the prepackaged software index. In our "liberal" alternative scenario, we deflate own-account and custom software with an index created with one-third weight on pre-packaged software and two-thirds weight on existing BEA deflators for the respective categories. ${ }^{14}$

\section{$\underline{\text { IT Investment as a Whole }}$}

All told, declines for the official price index for information technology slow dramatically from 6 percent per year for 1995-2004, to 1 percent per year for 2004-2014. Although the alternative index consistently falls faster than the official price, it slows to a similar degree—-from 9 percent per year for 1995-2004 to 4 percent per year for 2004-2014. The liberal index accelerates as well and provides essentially the same picture. Thus, on first examination, increasing mismeasurement does not appear to explain the slowdown in IT price declines when the available research from all periods is considered.

However, it bears emphasis that the composition of IT investment has shifted appreciably toward components for which measurement is more uncertain. Most notably, software investment has gone from 39 percent of IT investment for 1995-2004 to 48 percent for 20052014. Also, special-purpose equipment's share has increased, bringing the share for which measurement is more uncertain to 68 percent. Thus, our confidence in the IT price indexes, even as amended in the alternative indexes, has deteriorated markedly because of compositional shifts.

\footnotetext{
${ }^{14}$ Byrne and Corrado (2016) have added estimates of an alternative price index for software since this paper was written. Their price index accelerates by roughly the same amount (1.9 percent) as the price index we employ (1.7 percent). Consequently, the contribution of IT price mismeasurement to the productivity slowdown would not change if we employed their index. Their price index falls 3 percentage points faster in both periods, implying a somewhat greater contribution to labor productivity of capital deepening and smaller contribution of TFP both before and after 2004, but roughly the same acceleration of TFP.
} 


\subsection{Intangibles beyond the NIPAs}

Conceptually, capital investment represents the use of resources that "reduces current consumption in order to increase it in the future” (Corrado et al, 2009). Tangible investments in equipment and structures clearly meet this definition. But a lot of intangible spending by businesses and governments also meets this definition. The U.S. national accounts include some intangibles_-R\&D and artistic originals (history beginning in 1925 introduced in 2013) and software (history beginning in 1960 introduced in 1999) — as final fixed capital formation. However, businesses undertake considerable other spending that has the same flavor—such as training, reorganizations, and advertising.

Corrado et al (2009) and McGrattan and Prescott (2012) argue that investment spending has increasingly shifted towards intangibles, including those that are not currently counted. Basu, et al (2004) argue that reorganizations associated with IT can explain some of the dynamics of measured U.S. and U.K. aggregate TFP growth.

In the next subsection, we consider the effects of incorporating additional intangibles from Corrado and Jäger (2015). Their (updated) U.S. intangibles data run from 1977-2014. Ordered from largest to smallest estimated values in 2014, their data include investments in organizational capital; branding; training; design; and finance/insurance new products.

\subsection{Capital mismeasurement and TFP}

To help interpret the counterfactuals in the next subsection, we highlight here the conceptual reason why capital mismeasurement is unlikely to explain the past slowdown in TFP growth: It affect inputs as well as output in largely offsetting ways.

Consider a stylized example for a closed economy. Suppose that after some date in the past, we miss $q$ percentage points of true investment growth. The miss could reflect an increase 
in unmeasured quality improvement (relative to whatever we were missing prior to that date) or an increase in the importance of unobserved intangible investment.

The growing mismeasurement implies that true output and true labor productivity grow at a rate $s_{I} q$ faster than measured, where $s_{I}$ is the investment share of output and, by assumption, the good is completely produced domestically. It also implies that true capital input grows more quickly than measured. In steady state, the perpetual inventory formula implies that capital grows at the same rate as investment, so capital input also grows $q$ percent per year faster.

Thus, the change in TFP growth is the extra output growth less the contribution of the additional capital growth. In steady state, the change is $\left(s_{I}-s_{K}\right) q$, where $s_{K}$ is capital's share in production. In the data (and a condition for dynamic efficiency), $s_{I}<s_{K}$. Hence, in steady state, capital mismeasurement makes true TFP growth slower, rather than faster, than measured. ${ }^{15}$

Of course, this is a steady-state comparison. The initial effect is that output responds more quickly than capital input, so that TFP is temporarily increased. Also, some domestically produced capital goods are exported, and some goods used for investment are imported. It is thus an empirical question which effect dominates over particular time frames. ${ }^{16}$

\subsection{Simulations: Mismeasurement of durables worsens the slowdown}

We now assess the quantitative importance of mismeasurement of durable goods. As discussed above, this mismeasurement was large in the past, as well—and domestic production was more important. As a result of both factors, mismeasurement of productivity appears less important now than in the past. As a result, with consistent measurement, the labor productivity

\footnotetext{
15 Though not original to them, Basu et al. (2004) make this point in the context of intangible investment. Dale Jorgenson had made this observation to Fernald when software investment was added to U.S. GDP in 1999. ${ }^{16}$ Note, as well, that the slower pace of aggregate TFP growth would be distributed unevenly. Suppose the mismeasurement reflects faster true TFP growth in domestic equipment and software goods. Then TFP growth in the other industries must be slower than measured. Intuitively, this happens because growth in their capital input is more rapid than measured, but growth in their output is the same as measured.
} 
slowdown after 2004 becomes even larger than in the official data. For TFP, the adjustments are more modest but the slowdown is also a touch larger than in the official data.

We begin narrowly, with areas that are most grounded in a consistent methodology over time. This first “conservative” simulation considers alternative deflators for two categories of equipment for which considerable recent research has been done: Computers and peripherals; and communications equipment. (See the discussion in Section 2.1.1) We also consider alternative deflators for semiconductors. Those are primarily an intermediate input into other electronic goods but, because of exports and imports, revised deflators modestly affect final output growth. We then add more speculative adjustments for specialized equipment (NAICS 3345) and software. Finally, we add estimates of intangibles from Corrado and Jäger (2015).

Given alternative deflators and measures of intangibles, we adjust both output and input (capital services). An appendix describes the details. Output grows more quickly because of faster growth in domestically produced computers and other info-processing equipment. Importantly, some of these products are sold to consumers. Hence, the output adjustment also captures the effect on real GDP of consumer purchases of computers and communications equipment (such as mobile devices). Capital input grows more quickly because of the faster implied growth in computers and other information-processing equipment (whether domestically produced or imported).

For semiconductors, the adjustment to output only matters for GDP through its effect on net exports. In a closed economy, an adjustment that raises the true output of semiconductors is exactly offset by higher true intermediate input usage of semiconductors_-leaving GDP unchanged. However, in an open economy, semiconductors are exported and imported. We do not have separate adjusted prices for imported versus domestically produced semiconductors, so we assume that any adjustments are proportional. 
Column (0) of Table 2 shows our baseline from the published data. Measured labor productivity growth (top panel), capital deepening (middle panel), and TFP growth (bottom panel) sped up in the 1995-2004 period, but slowed thereafter. The slowdown in average annual labor productivity growth was about 1-3/4 percentage points. Some of that slowdown is explained by a reduced pace of capital deepening, leaving a slowdown in TFP growth of about 1$1 / 4$ percentage points. Labor productivity growth is especially weak after 2010 , though the growth accounting attributes this to the lack of capital growth relative to labor. Hence, TFP growth was about equally weak from 2004-2010 as from 2010-2014.

Column (1) then shows how results change relative to this baseline from adjusting computers, communications equipment, and semiconductors. As the top panel shows, these adjustments do affect labor productivity in a noticeable way. But the increase in the labor productivity growth rate is most pronounced for the $1995-2004$ period, at just under 0.3 percentage points. After 2004, the alternative deflators add only a little over 0.1 percentage points to growth. The reduced effect is due to the declining importance of domestic IT production relative to imports. Domestic production of computer and communications equipment amounted to 2.9 percent of nominal business sector value added in the late 1990s, but only 0.5 percent by 2014. A given amount of mismeasurement of computer and communication equipment therefore would have had a larger effect in the 1990s than today.

The middle panel shows that the adjustments have a substantial effect on capital services growth, as well. Again, the major adjustment is in the 1995-2004 period, when prices, by any measure, were falling rapidly. The bottom panel shows that the effect on TFP growth is small, but it goes in the direction of exacerbating the post-2004 TFP slowdown. Adjusted TFP is a little stronger than measured in the 1995-2004 period, but a little weaker after 2004. 
Column (2) adds more speculative adjustments for specialized equipment and software, as described above. The upward boost to output and labor productivity is a bit larger in each period than in column (1). But again, the upward boost is larger in the 1995-2004 period than in the post-2004 period, this time by almost exactly $2 / 10^{\text {ths }}$ of a percentage point. Adjusting capital goods, once again, turns out to exacerbate the slowdown in labor productivity growth. For TFP in the bottom panel, the adjustments also modestly exacerbate the TFP slowdown.

Column (3) adds intangibles from Corrado and Jäger (2015). With intangibles, the adjustments to labor productivity are even larger_-but, again, effects are largest in the 19952004. Together, the adjustments in column (3) add about half a percentage point to labor productivity relative to the published data in 1995-2004. From 2004-2014, the adjustments add only $2 / 10$ ths of a percentage point. Thus, the slowdown in labor productivity growth after the adjustments in column (3) is about $3 / 10^{\text {ths }}$ of a percentage point larger. For labor productivity, then, the adjustments taken together make the productivity slowdown markedly worse.

Other approaches to measuring intangibles (such as the more model-based approach of McGrattan and Prescott, 2012) might yield different results. Still, the results in column (3) suggest that the intangibles route is unlikely to alter the productivity slowdown.

Of course, the slowdown in capital growth, in the middle panel, also becomes much larger. As a result, in the bottom panel, the slowdown of TFP growth is affected by only a few basis points relative to the measured baseline. In particular, the adjustment subtracts $8 \mathrm{bp}$ from TFP growth in the $1995-2004$ period but then 12 bp during the $2004-14$ period. ${ }^{17}$ The important

\footnotetext{
${ }^{17}$ The careful reader will note that output growth $1995-2004$ is $1 / 10^{\text {th }}$ higher in column (3) than column (2), as is capital growth. So why does TFP growth fall, even though the output effect looks larger than the adjusted contribution of capital (capital's share times capital growth)? The reason is that, with intangibles, capital's share is also adjusted upwards, and so the effect on TFP involves not just the adjustment to capital growth, but also the adjustment to capital's share multiplied by (the new) capital growth rate. This effect can be a few tenths.
} 
takeaway is that correcting for capital goods mismeasurement does not resolve the post-2004 slowdown-if anything, it makes it worse.

We also experimented with an aggressive adjustment to software deflators after 2004, where true software prices are assumed to fall 5 percent per year faster than measured. This counterfactual captures the hypothesis that measurement has recently gotten worse, since only the post-2004 period is affected. Even that aggressive adjustment turns out to have relatively modest effects. The adjustment would add around $1 / 10^{\text {th }}$ percentage points to labor productivity growth after 2004. Yet capital growth is also higher in this simulation, and TFP is little changed.

The alternative deflators in this section imply faster TFP growth for IT-producing industries, but slower TFP growth for IT-using industries (since capital input grows more quickly without any adjustment in output growth). Nevertheless, as discussed in the appendix, the alternative deflators do not alter the broadbased nature of the TFP slowdown. With the alternative deflators, TFP growth for industries that produce IT and other investment goods slows sharply after 2004, as does TFP growth for other, non-investment-producing industries.

To summarize the takeaways from this section, prices for key capital goods are mismeasured and the mismeasurement varies over time. However, the effects of mismeasurement on productivity have been less, rather than more, important since 2004. Including intangibles, our adjustments add about 30 basis points to the slowdown in labor productivity but make the TFP slowdown only modestly larger.

Thus, if the productivity slowdown after the early 2000s indeed reflects mismeasurement, the source of the mismeasurement is not found in commonly studied IT durable goods. In the remainder of the paper, we find that growing mismeasurement of Internet services, e-commerce, fracking, and globalization (shown as “other” in Figure 1) can fill only a small part of the gap. 


\section{3. "Free" digital services}

The benefits to consumer well-being from online information, entertainment, social connection, and the like are large (e.g., Goolsbee and Klenow, 2006, Varian, 2011, and Brynjolfsson and Oh, 2014). Nevertheless, these benefits do not change the fact that marketsector TFP growth slowed broadly. Under long-standing national accounting conventions, the benefits are largely outside the scope of the market economy; as we discuss, given the small monetary size of the sector, it is very hard to bring many of the benefits inside the market boundary. The largest estimates of the gains are based on models of the time cost of using the Internet as an input into home production of non-market services. The gains from non-market production using the consumer's time are conceptually distinct from the gains in market sector output. And regardless of how they are treated, the non-market gains are not big enough to offset a significant fraction of the “missing” \$3 trillion per year in business output from the productivity slowdown.

In the standard national accounts approach, none of the output of online service providers whose revenue comes from selling ads is included in final consumption of households. Rather, their entire output is used for intermediate consumption of the advertisers.

Drawing on an earlier literature on free broadcast TV, Soloveichik (2015a) and Nakamura and Soloveichik (2015) propose an alternative approach that includes entertainment and information services supported by advertising in household final consumption. This approach prevents artificial changes in GDP when consumers switch between free and subscription-based media. The effect on the GDP growth rate turns out to be are miniscule, however, because advertising tends to be a small and relatively stable share of GDP. Further, this alternative approach has no effect on the nominal value added of the business sector by construction, leaving little scope for an effect on business sector productivity. Our "other” 
category of adjustments in Figure 1 therefore adds nothing to productivity growth in any of the periods for ad-supported digital services. Where we can get a small adjustment (about $1 \mathrm{bp}$ from 1995-04 and 4 bp from 2004-14) is for the improved quality of Internet service providers (ISPs) that is not included in the official deflators.

\subsection{The time cost approach to gains from free digital services}

The standard approach to measuring gains from new goods considers the difference between the amount of money that consumers would have been willing to pay and the amount that they actually had to pay. Yet the main “cost” to a user of, say, Facebook, YouTube or TripAdvisor, is the opportunity cost of the user's time. Hence, starting with Goolsbee and Klenow (2006), studies of the gains from free digital services have considered the time costs of using these services, and not only the money costs associated with accessing them.

Time costs are part of Becker’s (1965) model of the allocation of time. Suppose the representative consumer has the following utility function:

$$
U\left(Z_{I}, Z_{T V}, Z_{1}, Z_{2} \ldots\right)
$$

Households benefit from the consumption of (possibly unpriced) services from the Internet, $Z_{I}$, from television, $Z_{T V}$, and from other activities, $Z_{i}, i \subset\{1,2 \ldots\}$. The elements of $Z_{i}$ include meals at home, meals in restaurants, having a clean house, playing soccer, skiing, and so forth.

In this Becker-style model, the $Z_{i}$, are not the direct purchases of market goods and services. Rather, households combine purchased market goods and services with their own time to generate the actual services they value. They buy a soccer ball (which is part of GDP), and combine that market purchase with their (leisure) time, and their children’s time, to obtain “soccer services.” They combine a market purchase of a restaurant meal with several hours of their time. They combine gasoline and a car (both purchased in the market) with their time in 
order to go on a vacation that they enjoy. They combine a hotel room with their time to get a refreshing night of sleep during that vacation. Broadly, the services take the form:

$$
Z_{i}=g_{i}\left(C_{i}, T_{i}, Q_{i}\right) \subset\{I, T V, 1,2 \ldots\}
$$

Playing soccer generates services from the market consumption of a soccer ball, $C_{i}$; the time spent playing soccer, $T_{i}$; and, possibly, technical change $Q_{i}$ in the household's production function for combining the market purchase with time.

Now consider a stylized problem that captures the key issues in valuing the Internet. Households seek to maximize well-being subject to cash and time budget constraints:

$$
\begin{gathered}
\operatorname{Max} U\left(Z_{I}\left(C_{I}, Q_{I}\left(1-\tau_{I}\right) T_{I}\right), Z_{T V}\left(C_{T V},\left(1-\tau_{T V}\right) T_{I}\right), Z_{3}\left(C_{3}, T_{3}\right), Z_{4}\left(C_{4}, T_{4}\right) \ldots\right) \\
\text { s.t. } \sum_{i} P_{i} C_{i}+F_{I}+F_{T V}=W T_{\text {Work }} \\
T_{\text {Work }}+T_{I}+T_{T V}+\sum_{i} T_{i}=1
\end{gathered}
$$

In the cash budget constraint (2), income is the wage, $W$, multiplied by time spent working, $T_{\text {Work }}$. In the time budget constraint (3), total time is normalized to one. In other words, time spent working is time not spent doing other activities. Households purchase broadband access $C_{I}$, via cable or mobile phone or other means by paying a fixed or flat cost each period of $F_{I}$. The Internet services that they actually value then depends on the time they spend online, $T_{I}$, net of a flow "time tax" $\tau_{I}$ which is proportional to their use of the Internet. For example, they get "free" access to YouTube videos in exchange for spending a proportion of their time watching ads.

As in Brynjolfsson and Oh (2014), Internet content may get better over time, as captured in quality $Q_{I}$. $Q_{I}$ captures the growing number of web sites you can visit, or the number of videos available on YouTube, or whether your friends are on Facebook. These are conceptually distinct from download speed or other characteristics of your Internet service provider (ISP). Those 
characteristics conceptually represent a larger quantity of $C_{I}$. (As we discuss below, not all of those characteristics are currently in the implicit deflator for Internet access.)

Television is similar to the Internet. You may pay a fixed cost for watching TV, $F_{T V}$, as well as paying a time tax, $\tau_{T V}$, again in the form of watching ads. Historically in the United States, prior to cable TV, $F_{T V}=0$, and the entire service provision was paid for through watching ads. For other goods, the price is $P_{i}$.

This formulation illustrates the key issues, but does make simplifications. For example, it ignores non-wage income, as well as durable goods, such as computers and cell phones and TVs and beds; it assumes that households are unconstrained in their time allocation so that the marginal opportunity cost of time is the (fixed) wage; it ignores any extra disutility associated with working or with other activities. Schreyer and Diewert (2014) discuss extensions to the Becker framework.

It is useful to combine the money and time budget constraints as

$$
\left(\sum_{i} P_{i} C_{i}+F_{I}+F_{T V}\right)+W\left(T_{I}+T_{T V}+\sum_{i} T_{i}\right)=W
$$

"Full expenditure" in this setup is the sum of market expenditures (the first term in brackets) and the monetary value of non-market expenditures of time (the second term). Some non-market expenditures could be on home production of goods and services that are a close substitute for market goods and services, such as cooking and cleaning. Others are for leisure (surfing the Internet for personal reasons, watching TV, playing soccer, and so forth). Some are in the 
middle, such as Wikipedia, where unpaid content writers create and edit entries for the personal enjoyment of it, but it substitutes for market encyclopedia services. ${ }^{18}$

The core national accounts measure the prices and quantities that correspond to market activities, which show up in the first bracketed term in (4). Nevertheless, the importance of nonmarket activities, the second term, has long been recognized. After all, Americans aged 15 and older spend only 15 percent of total time working, or 24 percent of non-sleeping time. ${ }^{19}$ Mackie et al. (2005) and Nordhaus (2006) discuss the need for non-market satellite accounts.

Based on increasing amounts of time spent online, Brynjolfsson and Oh (2014) estimate that the incremental consumer surplus from free digital services is sizeable, averaging \$25.2 billion for 2002-2011, with larger effects in the years after $2005{ }^{20}$ These incremental gains are the equivalent of adding about 0.3 percentage points per year to business-sector output and productivity growth. Adding these gains is not appropriate, however, if the question is the productivity of the economy in producing market goods and services. The gains implied by changes in the allocation of consumers' time are linked to home production of non-market services, not market output.

\subsection{Market production of new goods}

In contrast to the time-based estimates of the value of free digital services, the standard approach used to define the theoretical measure of real GDP implies that only a small amount of extra digital service output is missed, mainly reflecting download speed and other characteristics that are not currently included in the deflators for Internet access and cell service.

\footnotetext{
${ }^{18}$ In the GNU Manifesto, Stallman (1987) describes his vision that "In the long run...no one will have to work very hard just to make a living. People will be free to devote themselves to activities that are fun, such as programming.” (We thank Hank Farber for pointing us to this quotation.)

19 The American Time Use Survey at http://www.bls.gov/tus/tables/a1_all_years.xlsx (accessed February 1, 2016).

${ }^{20}$ As a nonprofit institution serving households, Wikipedia’s output, about $\$ 0.2$ billion in 2011, is counted in the personal consumption. The $\$ 25.2$ billion thus overstates the adjustment that could be made to GDP by $\$ 0.2$ billion.
} 
Real household consumption and real GDP measure changes at the margin, not total amounts of consumer surplus. Hence, even if free digital services belonged in market-sector GDP and provided a large amount of consumer surplus, the growth-rate effects would not necessarily be large. What would matter is the incremental consumer surplus from a change in the consumption of the digital services.

For existing goods, the BEA’s chained Fisher index of real personal consumption expenditures correctly captures the change in consumer surplus. ${ }^{21}$ For an existing free good, the correct weight on any change in quantity is zero because consumers adjust the quantity consumed of each good (excluding those at a corner solution of zero) so that the value of the marginal unit consumed is proportional to the price.

On the other hand, new goods bias can arise even if the good enters at a price of zero. The measurement theory for new goods imagines that the new good previously existed but was offered at the "virtual price" that just drove demand to zero. The area under the demand curve from the virtual price down to the actual price of the good after it entered gives the consumer surplus from the appearance of the new good. Some major free digital services, including Facebook, YouTube, and Google Maps, appeared after the start of the productivity slowdown, but on the other hand, some free digital services disappeared, leading to welfare losses.

Yet free digital services are not costless to consume because they require Internet access. The price of the required Internet access can be viewed as the price of a bundled commodity, where the free digital services are part of the bundle. With an assumption about slope and curvature of the demand curve for the bundled commodity, increased spending on Internet access

\footnotetext{
${ }^{21}$ The online appendix shows that the Laspeyres and Paasche quantity indexes that are averaged to obtain the Fisher index are upper and lower bound measures of the relative change in consumer surplus.
} 
to enjoy the new free services could be used to estimate the gains from this new available bundled commodity.

We do not make such an estimate in the present paper, but an indication of its magnitude comes from estimates of welfare gains from Internet access. Greenstein and McDevitt (2009), for example, use data on the replacement of dial-up Internet access with broadband, and estimate that the uptake of broadband generated an average of $\$ 0.3$ billion per year in unmeasured consumer surplus in 1999 and 2003, and an annual average of just over \$1 billion in 2004-2006. Brynjolfsson and Oh (2014) extend the Greenstein and McDevitt analysis, adding an adjustment for increased consumption of services per hour, as measuring by rising data usage patterns. They find that this "money measure” of the gains from improved ISP services (i.e., the part that would be appropriate to add to market sector output) are a little larger, but still small—averaging only $\$ 2.7$ billion per year (2 to 3 basis points of business output).

This analysis of the monetary mismeasurement applies only to Internet access at home, not mobile access. Using the Brynjolfsson-Oh data on improved quality of Internet access, and assuming that the increase in the mobile share after 2004 reflects mobile data that is subject to the same unmeasured quality improvement raises "true” output and productivity by 1 bp in the 1995-2004 period and by 4 basis point after 2004. We include this adjustment in the "other" category in Figure $1 .^{22}$

\subsection{Alternative treatment of advertiser-supported digital services}

$$
\text { Internet businesses make money in part by creating content that users value. Is it }
$$
reasonable to exclude this entirely from GDP, just because they do not involve a monetary cost

\footnotetext{
${ }^{22}$ We thank JooHee Oh for sending their data. Our calculation corresponds to their equation (14) on the money benefits.
} 
to households? We now consider an alternative that brings some of these otherwise omitted advertising-supported digital services into household consumption.

Some free digital services are, in fact, already included in GDP, namely those provided by nonprofit institutions such as Wikipedia. But most free digital services are supported by advertising. ${ }^{23}$ The national accounts treat advertisers as intermediate consumers of the services of a business whose revenue comes entirely from advertising. For example, broadcast TV services have long been counted in the national accounts as an intermediate input: Companies buy advertising, so major broadcasting networks such as ABC or NBC are like ad agencies. Many Internet services have that same treatment: Facebook and Google provide advertising services to businesses, not services consumed by households.

Nakamura and Soloveichik (2015) propose a framework for including ad-supported entertainment and information services in households’ consumption that draws on an earlier literature on how to treat broadcast television in national accounts. They value the services given to households at their cost of production. The framework is based on the observation that consumers implicitly pay for the entertainment and information by watching ads (or, in some cases, providing valuable personal information). The "time taxes" $\tau_{I}$ and $\tau_{T V}$ were not included in the cash budget constraint (2) because they do not have an explicit price. But we can express $W T_{I}$ (the time value associated with the Internet in equation (4)) into $W \tau_{I} T_{I}+W\left(1-\tau_{I}\right) T_{I}$, where the first term is part of a "market oriented" barter transaction that can be imputed between households and firms. In this barter transaction, the time that consumers spend viewing ads is a service purchased from households by providing entertainment or information services.

\footnotetext{
${ }^{23}$ Another revenue source for providers of free digital services is the valuable information that the users of these services reveal about themselves, but this is a small revenue source compared to advertising.
} 
When these “free” entertainment/information services are added to households’ consumption, GDP goes up by the value of the extra household consumption. But the national accounts need to balance-someone has to produce the extra value added. The TV networks or the providers of the digital services have the same inputs of capital and labor; and their measured value added does not change. Rather, on the production side, the rise in GDP can be traced to households' production of “ad-watching services.” With no change in the output consumed by the advertisers, recording output sold to households requires us to impute an equivalent amount of purchases of services from consumers who view the ads.

This approach is reasonable: it monetizes an implicit barter transaction that consumers undertake with Google and Facebook and other advertising-supported service providers, and it recognizes that consumers value the services they receive. Nonetheless, treating consumers as suppliers of ad-watching services and as consumers of free digital services does not change the business sector's nominal value added: the ad-watching services are outside the boundary of the business sector. ${ }^{24}$ If the deflators are the same, business-sector TFP will also be unaffected because the intermediate inputs of the ad-watching services that are added on the input side of the productivity calculation will exactly offset the "free" entertainment and information services that are added on the output side. On the other hand, it is possible for the deflators to vary in a way that raises business TFP if ad viewing, and delays caused by the time it takes to download the ads, take up a falling proportion of time spent consuming digital services.

\footnotetext{
${ }^{24}$ In work in progress, Fernald and Reinsdorf (2016) discuss a way to bring the extra value added into the business sector, as opposed to being in the household sector. Their approach requires special treatment of the advertising revenue, so that some of the output that is currently viewed as intermediate consumption by the ad buyers can instead be viewed as consumed by households. This would make business sector nominal and real value added larger but the effect on TFP growth is still close to zero. A separate issue is that a more explicit agreement for consumers to watch the ads in order to receive the services would be required for the ad watching to qualify as a barter transaction under international guidelines of the System of National Accounts (United Nations, et al., 2009, para. 3.51 and 3.53).
} 


\subsection{Significance of free digital services for productivity measures}

The effect on the level of GDP from allocating part of output of the providers of free entertainment and information services to household final consumption is limited because advertising is only a small share of GDP. When services to households from traditional print and broadcast media are included along with digital services, the level of U.S. GDP shifts up by about 0.5 percent (Soloveichik, 2015b). The effect on the growth rate of real GDP is smaller still. In Nakamura and Soloveichik (2015, Table 3) real advertising services have an average growth rate of 2 percent from 2004 to 2013, while the real output of the business sector used in productivity measurement grows at just over 1.5 percent per year. Assuming that the real growth rate of the advertising-supported services was the same as the real growth rate of the advertising and using a share weight of 1.3 percent of business sector output implies an upward revision of less than 1 basis point to productivity growth in the slowdown period. But the pre-slowdown adjustment is similar or larger, so this adjustment does not reduce the size of the productivity slowdown. In our benchmark set of "other" adjustments, we round the effect to zero.

How sensitive is this benchmark to the advertising deflator? That deflator may have a "new goods bias" caused by the emergence of online advertising if that is a more efficient technology for delivering ads. Soloveichik’s (2015b) estimate of the 2012 cost per viewer-hour of an online advertisement is 11 cents, compared with 54 cents for broadcast TV. The lower cost of attracting ad viewers by providing free digital services suggests that the substitution of online advertising for traditional media advertising may involve a productivity gain in ad delivery. Facebook, for example, does not have to pay to acquire content because consumers themselves create the content, making the cost of attracting users to the website quite low.

Suppose the quality-adjusted price for online advertising is half that of traditional media. A unit value price index would capture the "outlet" substitution effect as ad buyers switch to 
online advertising. The market share of online advertising rose from 7 percent in 2004 to 27 percent in 2013 (Nakamura and Soloveichik, 2015), implying an average annual growth rate adjustment of -1.9 percent per year. With a 1.3 percent weight of advertising in the output of business, the implied adjustment to productivity growth would rise to about 2-1/2 bp per year. Finally, we note that some of the welfare benefits of free digital services involve better choices of where and what to buy. Information from TripAdvisor or Yelp may improve restaurant selection (and even have dynamic spillover effects as bad restaurants improve or exit.) In addition, online information and online shopping have expanded the set of available varieties. Moreover, the Internet has also brought about new markets for used goods through websites such as eBay and Craig's List. A cost of living index that measured the gains from improved matching of products and product varieties to consumers' preferences and circumstances might show substantial gains (even beyond the e-commerce benefits discussed below). Making more efficient use of what we have raises welfare, but does not represent an outward shift in market output or even the production possibility frontier that is achievable with a given factor endowment. ${ }^{25}$

Divergences between welfare change and real GDP from IT-enabled shifts between market production and non-market production arise in other contexts, as well. For example, tax software has reduced reliance on paid tax preparers, and apps such as Skype and WhatsApp have reduced spending on phone calls and text messages. Yet it is worth remembering that welfare changes from substitution between non-market activity and the market activity are not new. In the early $20^{\text {th }}$ century, for example, paid domestic workers did many tasks that by mid-century had been taken over by the households themselves. Conversely, home appliances such as

\footnotetext{
${ }^{25}$ A well-known example the need to distinguish between increases in welfare and productivity gains occurs with changes in terms of trade. Favorable shifts in export and import increase the opportunity to gain from trade, allowing real consumption to rise as the economy moves to a different point on the production possibility frontier.
} 
washing machines served as “engines of liberation” (Greenwood, et al., 2002) that dramatically increased labor-force participation by women.

Furthermore, though non-market and market production are somewhat substitutable in generating consumer welfare, many questions about economic growth require a concept of productivity that covers only the output and inputs of the market sector. Imputations for nonmarket output would make the productivity measure more subjective and model-driven, as opposed to data-driven. Gains in non-market output and their contribution to welfare, though important, are best treated as a separate concept from productivity change.

\section{E-commerce and gains in variety and match quality}

E-commerce has grown rapidly in importance, both for business-to-business (B2B) and business-to-consumer transactions. In this section, we estimate that the growing unmeasured benefits to consumers contributes about 2 bp to the productivity slowdown. B2B e-commerce has made intermediate transactions more efficient but, in principle, does not directly cause mismeasurement of aggregate productivity. Indirectly, however, it can complicate productivity measurement through its effects on outsourcing and the reorganization of production into global supply chains. The next section considers those effects in the context of globalization.

According to the Census of Retail Trade, the share of e-commerce in retail sales has risen about $1 \frac{1}{2}$ percentage point per year since 2000—from 0.9 percent in 2000 to 2.1 percent in 2004, 5.3 percent in 2012, and 7.3 percent in $2015 .{ }^{26}$ The steady shift in purchasing patterns reflects

\footnotetext{
${ }^{26}$ https://www.census.gov/retail/mrts/www/data/excel/tsnotadjustedsales.xls (accessed April 6, 2016). The Census Bureau defines e-commerce as purchases made over the Internet or other electronic network or via email. The ecommerce shares for products that are easy to order online (such as books) are even larger, since some products (e.g., gasoline and building supplies) presumably involve little e-commerce. Evans et al. (2016) conjecture that the Census figures underestimate e-commerce.
} 
the gains to consumers in terms of savings of time and transportation costs, as well as the ability to search over a much broader range of varieties.

For online books, Brynjolfsson, Hu and Smith (2003) estimate the gains from increases in variety available on Amazon and other websites. They consider obscure book titles as new goods, since these would have been hard to find at brick-and-mortar stores. The compensating variation from a new good with a constant price elasticity of $\alpha<-1$ can be approximated by dividing its post-entry sales by $1+\alpha$. In 2000 , out of $\$ 24.59$ billion in total book sales, the authors estimate that $\$ 578$ million were from online purchases of obscure titles. Depending on the assumed elasticity, the compensating variation was in the range of \$731 million to \$1.03 billion, or around 3 to 4 percent of total book sales that year.

This approach probably overestimates the gains by assuming a constant demand elasticity all the way back to y-axis and by ignoring losses in consumer surplus from the disappearance of brick-and-mortar bookstores. Feenstra (1994) derives a more conservative formula for the unmeasured gains from net variety growth based on a CES model with the elasticity of substitution $\sigma>1$. Let $\lambda_{\mathrm{t}}$ equal 1 minus the share of expenditures in period t going to new varieties and $\lambda_{0}$ be 1 minus the share of expenditures in period 0 going to varieties that disappear in period 1 . Then the welfare change from changing availability of varieties can be calculated by multiplying the CES price index for the continuing varieties by a factor of $\left(\lambda_{t} / \lambda_{0}\right)^{1 /(\sigma-1)}$. The elasticity of substitution between different varieties of the same good is usually high. With $\sigma=4$ and an assumption of no variety disappearances, the 2.35 percent market share garnered by obscure book titles made newly accessible by the Internet implies a correction to the price index of -0.8 percent, while with a relatively low assumption for $\sigma$ of 3 the bias becomes -1.2 percent. These gains accumulated over a period of several years, so the annual bias is smaller. 
Books, of course, are just one type of good with increased availability of varieties online. Suppose we view e-commerce itself as a sort of new variety. Using the Census shares and assuming $\sigma=4$, the correction factor to the price index for retail goods falls 15 bp per year from 2004-2014, compared with 8 bp per year from 1995 to 2004 (assuming the online share was zero in 1995). Personal consumption expenditures on goods amount to about 25 percent of the gross value added of business excluding housing. Using this as a weight on the bias in the retail sales price index implies an upward correction of just under 4 bp per year in business sector productivity after 2004 and about 2 bp per year from 1995-2004. Thus, correcting for gains from e-commerce shaves perhaps 2 basis points from the productivity slowdown.

\section{Fracking and globalization}

Fracking and globalization are two areas where mismeasurement has plausibly contributed in a meaningful way to the slowdown in measured productivity growth. Fracking is a technological innovation that allows drillers to access lower "quality" natural resources. A backof-the-envelope calculation suggests that unmeasured aspects of this innovation raise true aggregate labor and TFP growth by around 5 basis points per year since 2004. For globalization, import price declines from offshoring and related changes in import sourcing are largely missed, so true import growth is understated in the late 1990s and early 2000s (the time of China's WTO accession); correspondingly, growth in GDP, labor productivity and TFP are overstated. This globalization adjustment shows up as a negative contribution of about 10 bp from 1995-2004 and -2 bp from 2004-2014 for the "other” category in Figure 1.

\subsection{Technological innovation in oil and gas: the Fracking Revolution}

In the industry TFP data discussed in Section 1, oil and gas extraction had strong TFP performance in the 2007-2013 period. Nevertheless, the standard measure of TFP for mining 
does not control for variation in the "quality" of the natural resources being extracted, so it is not a pure measure of technology. Technological innovations that made it possible to extract oil and gas from previously uneconomic geologic formations diffused rapidly in the 2000s. This type of technological change is unlikely to be fully reflected in the statistics. Hence, true growth in mining investment in structures capital is almost surely faster than measured. At the same time, a key input (the subsoil reserves component of land) that is not included in the traditional approach to measuring mining productivity fell in quality.

A cost-effective way to extract natural gas from shale using horizontal drilling and hydraulic fracturing (fracking) was discovered in the late 1990s. Over the next decade, this technique was improved and extended to the extraction of oil from shale and other low permeability formations. As a result, the last half of the 2000s saw a remarkable resurgence in US oil and gas production (Figure 7). Import facilities for liquefied natural gas (LNG) have been hastily repurposed as export facilities, and OPEC has changed its pricing strategy.

The fracked wells are like a new good whose benefits are not counted by conventional measures of TFP. Nordhaus and Kokkelenberg (1999, pp. 63-64) observe that deposits of an exhaustible natural resource vary in their extraction costs. Above some cutoff level of rent (the difference between extraction cost and the market price of output) extraction does not occur. Suppose that technological progress reduces the unit cost of extraction for all deposits. Now, $\pi>1$ units can be extracted from any given deposit in period 1 with the same inputs of labor and capital that produced 1 unit in period 0 . The output price is set on world markets and does not change, and neither does the cutoff level of rent for extraction to be undertaken. Deposits that were previously uneconomic now begin to be extracted. The level of productivity at the least productive establishment remains constant, while that of the most productive establishment rises from $\lambda_{0}^{\max }$ to $\lambda_{1}^{\max }=\pi \lambda_{0}^{\max }$. Assuming productivity levels are uniformly distributied across 
establishments from 1 to $\lambda_{0}^{\max }$ and that all establishments are identical in size as measured by inputs, measured productivity growth for the industry, denoted by $\hat{\pi}-1$, equals:

$$
\hat{\pi}-1=\frac{1+\pi \lambda_{0}^{\max }}{1+\lambda_{0}^{\max }}-1=\frac{\lambda_{0}^{\max }}{1+\lambda_{0}^{\max }}(\pi-1)
$$

For example, if $\lambda_{0}^{\max }=2$, only two-thirds of true productivity gains would be measured.

A proper accounting for the quality of land as a factor of production would capture the gains. Deteriorating land quality would imply slower growth of inputs than in the official data, and TFP would growth faster. ${ }^{27}$ Careful measurement of land services in mining —and elsewhere-is challenging. In the BLS productivity data, oil and gas extraction appears to use almost no land, because the value of rights to extract subsoil mineral deposits is included in services of fixed capital assets (which consist largely of structures). Alternative productivity measures for Australian mining published by the Australian Bureau of Statistics ${ }^{28}$ imply that roughly half the conventionally measured services of fixed capital assets actually represent services of subsoil natural resources. We assume that this relationship holds for the U.S.

Accounting properly for technological progress in oil and gas industries requires not only an assessment of land quality changes, but also quality-adjusting the fixed assets that embody the technological improvements. These consist primarily of oil and gas wells drilled for exploration or development purposes. The quality adjustment would reflect the cost reduction made possible by better technology while holding constant the mix of deposits being exploited.

\footnotetext{
${ }^{27}$ Brandt et al. (2014) discuss an alternative approach to measuring multifactor productivity for mining that includes services of natural resource assets. The Australian Bureau of Statistics (ABS) publishes an experimental measure of MFP for mining that includes services of subsoil natural resource assets in inputs. In the tables released in December 2015, this raises the estimated growth rate of mining MFP over 2000-01 to 2014-15 from -4 percent per year to -1 percent per year. Similarly, Zheng and Bloch (2014) find that adjusting for inputs of natural resources, declining returns to scale and capacity utilization raises MFP growth for the mining industry of Australia between 1974-75 and 2007-08 from -0.2 percent per year to 2 percent per year.

${ }^{28}$ Downloaded at http://www.abs.gov.au/AUSSTATS/abs@.nsf/DetailsPage/5260.0.55.0022014-15.
} 
In the post-2004 period the average share of investment in oil and gas structures in value added of business is about 0.9 percent. But, plausibly about half of that, or about 0.5 percent of business output, is the structure itself (which is improving faster than measured); the remainder is actually the subsoil asset (where the quality is getting worse). In terms of output (i.e., final investment), suppose there is a fairly large true quality adjustment to the price index for oil and gas extraction structures of 10 percent per year after 2004. Multiplying that by the roughly 0.5 percent share of business value added implies that true investment is about $5 \mathrm{bp}$ faster. That goes directly into the "other" portion shown in Figure 1, boosting true labor productivity in the post2004 period. For TFP, the question is how much capital is improving and land is deteriorating. As a rough first pass, we assume the two effects offset-leaving measured capital growth about right. In that case, the 5 bp increment to labor productivity also passes through to aggregate TFP.

\subsection{Globalization}

Standard techniques for constructing price indexes do not capture the change in the average price paid by the buyers of a product when they alter their purchasing patterns to buy from a different seller. Similarly, import price deflators in the NIPAs do not capture changes in the price paid by buyers when they switch from a domestic source to an offshore producer. As a result, when sourcing moves offshore or to a different import-supplying country, real imports are understated and real output is overstated. ${ }^{29}$

This bias was particularly significant in the late 1990s and early 2000s, when the location of many kinds of manufacturing was shifting rapidly from the US and other countries with high labor costs to emerging market economies. One impetus for this was China's 2001 accession to the World Trade Organization (WTO), which coincided with the start of a large shift in the

\footnotetext{
${ }^{29}$ Houseman, et al. (2010 and 2011) and Mandel (2009) examine this problem.
} 
sourcing for many manufactured goods used in the US to China. Another was a multilateral free trade agreement that reduced tarrifs for IT products to zero over an interval of four years ending in 2000, which accelerated international sourcing changes for IT products (Feenstra, et al., 2013). Reinsdorf and Yuskavage (2015) use two approaches to estimate the sourcing bias for imported consumer goods in 1997-2007 and find a bias in range of 0.8 to 1 percent per year for durable goods including computers, and around 0.6 percent per year for imported apparel and footwear. After 2007, the effect is small. However, even if we assume that the bias estimate of 1 percent per year for durable goods can be generalized to similar kinds of imported capital goods and that the bias in the apparel index can be generalized to all textile products, the upward bias in business TFP is only 0.1 percent per year because the affected imports have only a small weight in GDP. This globalization adjustment shows up as a negative contribution of 10 bp from 19952004 for the “other” category in Figure 1.

Another aspect of globalization made possible by reduced communications costs is international trade in services over a wire. The number of American jobs that could potentially be offshored to a country with lower wages is potentially large (Blinder, 2009), and the offshoring of services could lead to the same sort of upward bias in measures of productivity that is caused by offshoring of goods. Thus far, however, the effects have been modest: BEA's input-output accounts show that the imports of business process services such as professional scientific and technical services and computer systems services rose from around 2 percent of total intermediate uses of these services in 1997-98 to around 5 percent in 2010-2014. 


\subsection{The "Sharing" Economy}

Nominal GDP includes transactions from the sharing economy, such as rides on Uber and Lyft. $^{30}$ Nevertheless, it is unlikely that the deflator used to compare the new services to previously existing ones correctly measures the decline in quality-adjusted price experienced by many consumers. Thus, there is probably some (at this point very, very small, but likely growing) downward bias in the growth rate of real GDP.

It would be useful to have official statistics on the nominal output of the various types of services included in the sharing economy. Research indexes of price change could then be developed to try to calibrate the size of the bias.

\section{Conclusions}

The “productivity paradox 2.0” remains alive: Despite ongoing IT-related innovation, aggregate U.S. productivity growth slowed markedly after 2004 or so. We propose several adjustments to IT-related hardware, software, and services. The good news is that the adjustments make recent growth in GDP and investment look modestly better than recorded. The bad news is that it makes the paradox even worse- the slowdown in labor productivity is even larger after our durable-goods adjustments, while the slowdown in TFP is not much affected. The reason is that mismeasurement was substantial in the 1995-2004 period as well as more recently, and rising import penetration for computers and communications equipment means that domestic production (which matters for GDP) has fallen over time.

\footnotetext{
${ }^{30}$ Where they are in the source data is not clear, however: the Quarterly Census of Services indicates slowing nominal growth of the local transportation measure that includes taxis, which is where one would expect to find the new kinds of local transportation services.
} 
Moreover, the slowdown was broadbased, which suggests that ongoing innovation in IT is not substantially spilling over into other areas. Other measurement challenges, such as digital services, globalization, and fracking, go in the right direction but are small.

Other evidence also suggests that true underlying growth is relatively modest. First, the U.S. productivity slowdown has been mirrored in many parts of the world (Eichengreen et al., 2015; Cette, et al, 2016; Askenazy et al., 2016). This suggests underlying macroeconomic factors may be driving the slow pace of growth, given the varied sources and methods used across national statistical systems. Syverson (2015) finds that the slowdown across countries is not correlated with IT production or use, again suggesting that the problem is not mismeasurement related to IT goods or services. Second, the decline in economic dynamismboth in the form of fewer startups and slower reallocation of labor resources in response to productivity shocks — supports the idea that productivity-enhancing innovations are diffusing through the economy more slowly (Decker et al., 2016). Third, Mandel (2015) also finds little evidence of widespread rapid innovation in an analysis of labor market metrics such as occupational employment and help-wanted ads, although there are tremendous occupational changes in some narrow segments of the economy, such as IT and oil/gas extraction.

If not mismeasurement, why did productivity growth slow? The slowdown predated the Great Recession, which suggests that event was not the story_or, at least, not the whole story. Given that the 1970s and 1980s had similar slow growth to the period since 2004, the fastgrowth 1995-2004 period looks like the anomaly. With the emergence of the Internet, the reorganization of distribution sectors, and IT investments beginning to pay off, many things came together in a short period. With hindsight, that looks like a one-time upward shift in the level of productivity rather than a permanent increase in its growth rate. Looking forward, we could get another wave of the IT revolution. Indeed, it is difficult to say with certainty what may 
yet come from cloud computing, the Internet of things and the radical increase in mobility from smartphones. However, we have not seen those gains yet.

Changes in overall welfare are somewhat harder to assess. Transformative gains related to mobile technologies and the Internet clearly raise welfare. Most of those gains properly belong outside the purview of market-sector GDP_-and proposals to incorporate them into GDP raise concerns. Still, these innovations are valued by households. That said, the available estimates of the welfare gains (based on the value of leisure time) suggests that "free" digital services add the equivalent of perhaps 3/10ths percent of GDP per year to wellbeing. That is small relative to the 1-3/4 percent slowdown in labor productivity growth in the business sector from 2004-2014.

Nevertheless, much is unknown. Shapiro and Wilcox (1997) described the area of quality adjustment of price indexes as "house to house" combat in national accounting. The analysis must be done product by product, and statistical agencies are usually playing catch up. ${ }^{31}$ Digital services and the ensuing new modes of delivery of other services are particularly challenging. For example, research on quality-adjusted price indexes associated with changes in the organization of production caused by the digital economy, such as the substitution of Uber and Lyft for traditional taxi services, would be helpful. Satellite accounts could also help to shed light on gains from digital services and shifting of production outside the market boundary by presenting measures of economic activity that extend beyond the market.

Finally, we conclude with implications for policymakers. Slow productivity growth, if it persists, implies slow potential growth going forward. Benefits in the nonmarket sector can offset that somewhat for well-being, but it does not help with taxes or the budget.

\footnotetext{
${ }^{31}$ Wasshausen and Moulton (2006) discuss how statistical agencies incorporate quality adjustments.
} 


\section{Appendices}

\subsection{Appendix A: Data}

Fernald (2014) Quarterly Growth-Accounting Data (for Figure 1 and Table 2). Annual data run from 1948 through 2015, though our sample ends in 2014 because of the data for the output adjustments. Current vintage data are available at http://www.frbsf.org/economics/economists/jfernald/quarterly_tfp.xls. The vintage used for this paper was February 4, 2016. The dataset includes quarterly growth-accounting measures for the business-sector, including output, hours worked, labor quality (or composition), capital input, and total factor productivity.

Output is a geometric average from the income and expenditures sides. Hence, laborproductivity growth in Figure 1 differ slightly from the BLS Productivity and Cost data, which uses the expenditure-side. Capital input is a user-cost-weighted aggregate of capital input growth of disaggregated types of equipment, software, intellectual property, and inventories that are available quarterly, as well as land (interpolated from annual BLS estimates).

The chart below shows growth-accounting contributors to business-sector labor productivity:

\section{Contributions to growth in U.S. output per hour}

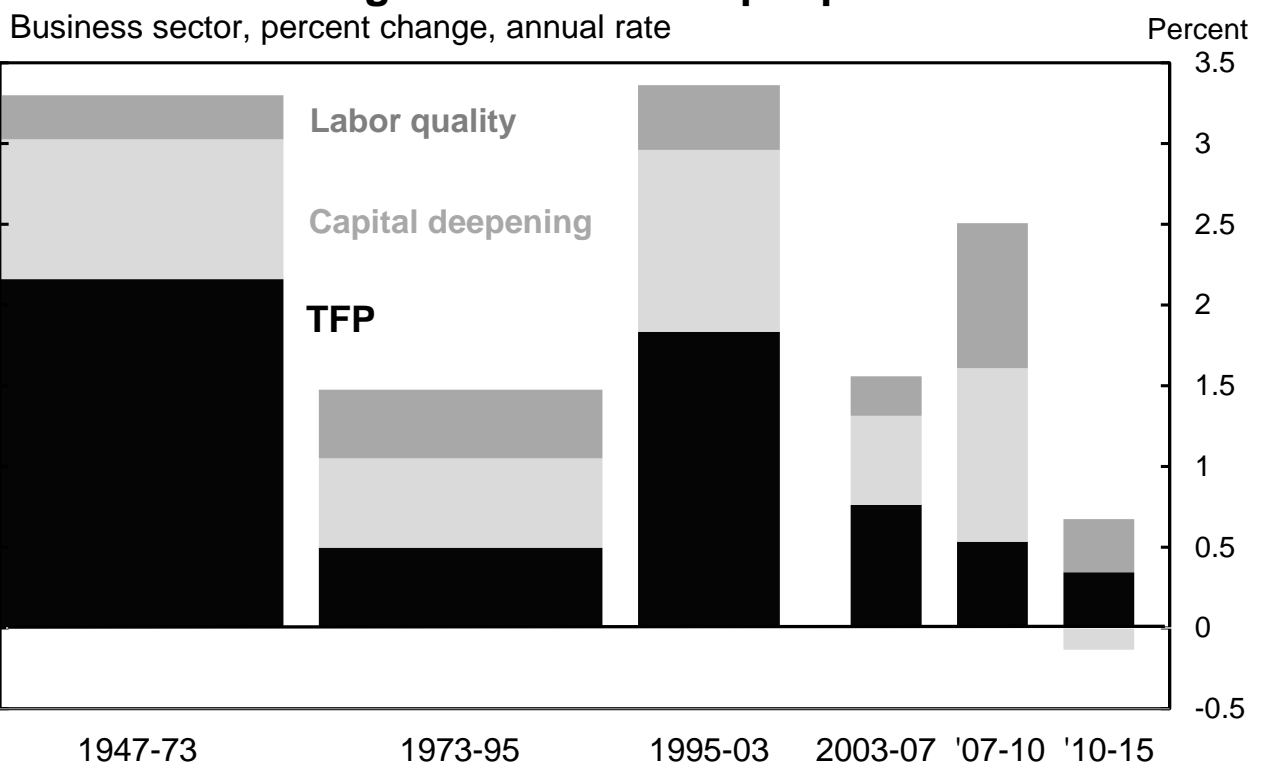

Source: Fernald (2014a). Quarterly; samples end in Q4 of years shown except 1973 (ends Q1). Capital deepening is contribution of capital relative to quality-adjusted hours. Total factor productivity is measured as a residual.

“Normal” productivity growth has varied substantially over the post-war period. Before 1973 and from 1995-2003, labor productivity rose at above 3 percent per year. In between, its growth rate averaged only about 1-1/2 percent per year. The slowdown in the early 2000s is statistically significant and predated the Great Recession. ${ }^{32}$

\footnotetext{
${ }^{32}$ Formal break tests justify the dates shown by the first three bars (see Fernald, 2014b).
} 
In the four years prior to the Great Recession (2003-2007), labor productivity rose at only about a 1-1/2 percent pace. Its growth rate then rebounded modestly during and (especially) immediately after the Great Recession (2007-2010). Yet, during the five years from the end of 2010 to the end of 2015, growth has been markedly lower.

The shaded regions of each bar show the contribution of standard growth-accounting components: labor "quality" (or composition), capturing changes in the educational attainment and experience of workers; capital deepening, or capital per quality-adjusted hour; and TFP, measured as a residual. ${ }^{33}$ The contributions of labor quality and capital deepening have varied somewhat over time, but the broad patterns in labor productivity largely track TFP growth.

According to the growth accounting, the weak performance in the final bar reflects capital "shallowing"-automation has been running in reverse. Mechanically, hiring has been extremely fast, with hours worked rising at about a 2 percent annual pace. In contrast, capital services have accelerated more slowly than hiring. To some extent, this reflects an unwinding of the strong pace of capital deepening during and immediately after the Great Recession:

Employment fell in the recession, leaving firms with plentiful capacity. In addition, labor quality added less than during the recession, when low-skilled workers lost jobs.

For alternative capital simulations discussed in the paper, we adjust deflators and real investment quantities for information processing and software. The simulations use published nominal values of nonresidential gross private domestic investment for computers and peripheral equipment, communications, and software (NIPA Table 1.5.5). The alternative deflators are then used to calculate alternative real investment series, which are then accumulated via perpetual inventory methods into real capital stock measures by assets. They are then aggregated with user costs into an alternative Tornquist index of real capital input.

The alternative capital deflators also imply differences in industry and sectoral TFP. Investment TFP growth is faster, but non-investment TFP growth is slower (because capital growth is faster). To understand whether the modifications in Section 2 change the broadbased nature of the TFP slowdown, we use relative prices to decompose aggregate TFP into growth of “investment” TFP, TFP Invest, and “other" (non-investment, mainly consumption) TFP, TFP Other $_{\text {. }}$ Suppose the two "sectors" have the same production functions (other than a multiplicative constant) and face the same factor prices. These are strong assumptions, but the literature on investment-specific technical change shows that it yields a sharp result: $\Delta \ln \mathrm{TFP}_{\text {Invest }}-\Delta$ $\ln \mathrm{TFP}_{\text {Other }}=\Delta \ln \mathrm{P}_{\text {Other }}-\Delta \ln \mathrm{P}_{\text {Invest }}$. This equation captures the intuition that the main reason why prices of consumption and other non-investment goods, $\mathrm{P}_{\mathrm{Other}}$, has been rising relative to the price of investment goods, $\mathrm{P}_{\text {Invest }}$, is the fast pace of technical progress in computers and other capital goods.

When we apply this decomposition using the counterfactual liberal deflators from Section 2.4, it does not change the broadbased nature of the TFP slowdown. (Results are not shown but are available on request.) Investment TFP growth is systematically stronger throughout history, whereas other (non-investment) TFP growth is systematically weaker. But after 2004, both investment and other TFP growth slow sharply, and by magnitudes that are similar to the base case that corresponds to Table 2, column (0).

\footnotetext{
${ }^{33}$ This standard measure of TFP does not adjust for cyclical effects on factor utilization. The Fernald (2014a) dataset does includes a model-based measure of factor utilization. Utilization adjustments turn out to make little difference in the subperiods shown here. Utilization had largely (though perhaps not entirely) reversed its sharp recessionary declines by the end of 2010. Of course, specific industries could be different.
} 
BLS Industry Data. Industry multifactor productivity (MFP) data were downloaded from http://www.bls.gov/mfp/mprdload.htm (accessed August 11, 2015). "Well measured" industries follow Griliches (1994) and Nordhaus (2002). IT-producing industries and wholesale/retail trade are broken out separately. "Other well measured" comprises manufacturing (excluding IT producing), agriculture, mining transportation, utilities, broadcasting, and accommodations. Everything else is in poorly measured. See Fernald (2014b) for further details.

Intangibles: Data are from Corrado and Jäger (2015), which in turn updates U.S. estimates from Corrado et al. (2009) and Corrado et al. (2012). Carol Corrado provided these unpublished data on nominal intangible investments from 1977-2014 (via email on February 12, 2016). To convert the data to real values, we deflate with the business-sector deflator. For initial capital stock values, we calculate investment growth rates $(g)$ for the first 10 years and then use the "steady state" formula that $K_{0}=I_{0} /(\delta+g)$, where $I_{0}$ is the initial real investment value and $\delta$ is the depreciation rate. The depreciation rates are from Corrado et al. (2009). For non-nationalaccount intangibles, we aggregate the intangible capital stocks into a Tornquist index using estimated user costs, assuming a constant real interest rate of 5 percent per year.

To aggregate intangible output with the Fernald quarterly TFP dataset, we use a Tornquist index. The weights are nominal business-sector output and nominal intangible spending. Similarly, we aggregate capital input with national-accounting measures with the new intangibles as a Tornquist index.

We also recalculate factor shares. Capital's share rises and labor's share $\left(s_{L}\right)$ falls. Intuitively, payments to labor do not change but nominal output is larger. Algebraically, the adjustment is $S_{L}^{\text {New }}=s_{L} P Y /(P Y+$ Intan $)$, where $P Y$ is measured business-sector factor costs and Intan is nominal intangible spending.

\section{Appendix B: Adjusting output}

For the simulations in Section 2.4, we adjust output (business-sector real GDP) as well as capital (described in Appendix A). This appendix shows that the main adjustment involves adding the Domar-weighted (i.e., industry nominal gross-output relative to aggregate value added) price adjustment to domestic gross output growth.

We start with the Tornquist approximation to the chained Fisher index of value added. From the national accounting identity, the change in aggregate value added growth is:

$$
d v=\sum_{i} w_{i} d v_{i}
$$

$d j$ is the log change in variable $J . \quad w_{i}$ is the value-added share of industry $i$. Industry valueadded growth, using the Tornquist (Divisia) formula, is:

$$
d v_{i}=\left(d y_{i}-s_{M 1, i} d n_{1, i}-s_{M 2, i} d n_{2, i}\right) /\left(1-s_{N 1, i}-s_{N 2, i}\right) .
$$

In this expression, $d y_{i}$ is growth (log change) in gross output. $d n_{1, i}$ is growth in an intermediate input (such as semiconductors) where we might want to adjust the price/quantity. $d n_{2, i}$ is the growth of intermediate inputs that are not affected by our adjustments. $s_{N, j}$ are the respective intermediate-input shares of the two types of intermediates.

Adjusting deflators implies new measures of output and of the first intermediate. The new growth rate is 


$$
d v_{i}^{N e w}=\left(d y_{i}^{N e w}-s_{N 1, i} d n_{1, i}^{N e w}-s_{N 2, i} d n_{2, i}\right) /\left(1-s_{N 1, i}-s_{N 2, i}\right)
$$

Thus, the adjustment to industry value added is:

$$
d v_{i}^{N e w}-d v_{i}=\frac{d y_{i}^{N e w}-d y_{i}}{\left(1-s_{N 1, i}-s_{N 2, i}\right)}-\frac{s_{N 1, i}\left(d n_{1, i}^{N e w}-d n_{1, i}\right)}{\left(1-s_{N 1, i}-s_{N 2, i}\right)}
$$

Thus, if there are no changes in input prices/quantities, the change in value-added is a "grossed up" version of the change in gross output. Conceptually, it is also necessary to adjust off the appropriately share-weighted change in intermediate-input prices/quantities as well. However, if the adjusted intermediate input (which we will take to be semiconductors) is domestically produced, we get a positive output adjustment for that industry, but then an offsetting adjustment for using industries. Therefore, we can ignore the second term-it is already captured by the adjustment below for semiconductors.

To see this effect, first note that $w_{i} /\left(1-s_{N 1, i}-s_{N 2, i}\right)=P_{i} Y_{i} / P V$, i.e., the Domar weight (nominal gross output relative to nominal aggregate value added). Therefore, the weight on the "output adjustment” is just the Domar weight. It follows that the second weight, on the intermediate input adjustment, is $s_{N 1, i} P_{i} Y_{i} / P V=P_{N, i} N_{i} / P V$.

Second, consider what happens when we adjust semiconductor prices. We add aggregate value added growth in (domestic) semiconductors, but then subtract the effect of domestic and foreign semiconductors used as intermediate inputs. Some algebra shows:

$$
\begin{aligned}
\sum_{i} w_{i} d v_{i} & =\frac{P_{S}^{D} Y}{P V}\left(d y_{S}^{D, \text { New }}-d y_{S}^{D}\right)-\sum_{i} \frac{P_{S}^{D} N_{S, i}^{D}}{P V}\left(d y_{S}^{D, N e w}-d y_{S}^{D}\right)-\sum_{i} \frac{P_{S}^{F} N_{S, i}^{F}}{P V}\left(d y_{S}^{F, \text { New }}-d y_{S}^{F}\right) \\
& =\left(d y_{S}^{D, \text { New }}-d y_{S}^{D}\right)\left(\frac{P_{S}^{D} Y-\sum_{i} P_{S}^{D} N_{S, i}^{D}}{P V}\right)-\left(d y_{S}^{F, \text { New }}-d y_{S}^{F}\right) \sum_{i} \frac{P_{S}^{F} N_{S, i}^{F}}{P V} \\
& =\left(d y_{S}^{D, \text { New }}-d y_{S}^{D}\right)\left(\frac{P_{S}^{D} X_{S}}{P V}\right)-\left(d y_{S}^{F, \text { New }}-d y_{S}^{F}\right) \frac{P_{S}^{F} N_{S}^{F}}{P V}
\end{aligned}
$$

The first term is the adjustment from domestic output (superscript $D$ ) multiplied by the nominal value of semiconductor exports relative to value added. The second effect is the adjustment to imported output $(F)$, multiplied by the value of semiconductor imports to value added. In a closed economy, where exports and imports are zero, this effect disappears.

In sum, for final products, we Domar-weight the adjustment to prices/quantities. For semiconductors, we use an export weight for domestic production, then subtract off an importweighted "foreign" adjustment.

We obtained annual values of domestic production from Board of Governors’ databases. 


\section{References}

Aeppel, Timothy. 2015. “Silicon Valley Doesn’t Believe U.S. Productivity Is Down.” Wall Street Journal, July 17, sec. US.

Aizcorbe, Ana, and Yvon Pho. 2005. Differences in Hedonic and Matched-Model Price Indexes: Do the Weights Matter?

Askenazy, Philippe, Lutz Bellmann, Alex Bryson, and Eva Moreno Galbis, eds. 2016. Productivity Puzzles Across Europe. S.l.: Oxford University Press.

Baily, Martin Neil, Robert J. Gordon, William D. Nordhaus, and David Romer. 1988. "The Productivity Slowdown, Measurement Issues, and the Explosion of Computer Power." Brookings Papers on Economic Activity 1988 (2): 347-431. doi:10.2307/2534534.

Basu, Susanto, John G. Fernald, Nicholas Oulton, and Sylaja Srinivasan. 2004. “The Case of the Missing Productivity Growth, or Does Information Technology Explain Why Productivity Accelerated in the United States but Not in the United Kingdom?” In NBER Macroeconomics Annual 2003, Volume 18, 9-82. The MIT Press.

Basu, Susanto, John G. Fernald, and Matthew D. Shapiro. 2001. "Productivity Growth in the 1990s: Technology, Utilization, or Adjustment?” In Carnegie-Rochester Conference Series on Public Policy, 55:117-65. Elsevier.

Becker, Gary S. 1965. “A Theory of the Allocation of Time.” The Economic Journal 75 (299): 493-517.

Berndt, Ernst R., and Neal J. Rappaport. 2001. "Price and Quality of Desktop and Mobile Personal Computers: A Quarter-Century Historical Overview.” American Economic Review 91 (2): 268-73.

— 2003. "Hedonics for Personal Computers: A Reexamination of Selected Econometric Issues." In $R \& D$, Education and Productivity", an International Conference in Memory of Zvi Griliches (1930-1999), August, 25-27.

Bils, Mark, and Peter J. Klenow. 2000. “Quantifying Quality Growth.” Working Paper 7695. National Bureau of Economic Research. http://www.nber.org/papers/w7695.

Blinder, Alan S. 2009. “How Many US Jobs Might Be Offshorable?” World Economics 10 (2): 41.

Boskin, Michael J., Ellen R. Dulberger, Zvi Griliches, Robert J. Gordon, and Dale Jorgenson. 1998. "Toward a More Accurate Measure of the Cost of Living: Final Report to the Senate Finance Committee from the Advisory Commission to Study the Consumer Price Index.” In , edited by Dean Baker, 5-77. Getting Prices Right: The Debate over the Consumer Price Index. Armonk, N.Y. and London: Sharpe.

Brandt, Nicola, Paul Schreyer, and Vera Zipperer, 2014. "Productivity Measurement with Natural Capital." Manuscript accessed April 1, 2016 at http://repository.cmu.edu/cgi/viewcontent.cgi?article=1007\&context=sem_conf 
Brynjolfsson, Erik, Yu Hu, and Michael D. Smith. 2003. "Consumer Surplus in the Digital Economy: Estimating the Value of Increased Product Variety at Online Booksellers.” Management Science 49 (11): 1580-96.

Brynjolfsson, Erik, and JooHee Oh. 2012. "The Attention Economy: Measuring the Value of Free Digital Services on the Internet.” http://aisel.aisnet.org/icis2012/proceedings/EconomicsValue/9/.

Byrne, David. 2015. "Domestic Electronics Manufacturing: Medical, Military, and Aerospace Equipment and What We Don't Know about High-Tech Productivity.” FEDS Notes, no. 2015-06-02.

Byrne, David, and Carol Corrado. 2015. "Recent Trends in Communications Equipment Prices.” FEDS Notes, no. 2015-06-02.

Byrne, David M. 2015. “Prices for Data Storage Equipment and the State of IT Innovation.” FEDS Notes, July.

Byrne, David M., and Carol A. Corrado. Forthcoming. "ICT Prices and ICT Services: What Do They Tell Us about Productivity and Technology?” Working paper.

Byrne, David M., Stephen D. Oliner, and Daniel E. Sichel. 2013. “Is the Information Technology Revolution Over?” International Productivity Monitor 25.

—. 2015. “How Fast Are Semiconductor Prices Falling?” Working Paper 21074. National Bureau of Economic Research.

Byrne, David, and Eugenio Pinto. 2015. “The Recent Slowdown in High-Tech Equipment Price Declines and Some Implications for Business Investment and Labor Productivity.” FEDS Notes, no. 2015-03-26.

Cole, Rosanne, Y.C. Chen, Joan A. Barquin-Stolleman, Ellen Dulberger, Nurhan Halvacian, and James H. Hodge. 1986. “Quality-Adjusted Price Indexes for Computer Processors and Selected Peripheral Equipment.” Survey of Current Business 66 (1): 41-50.

Copeland, Adam, and Andrew Miller. 2013. Seasonality and Prepackaged Software Price Indexes. BiblioGov.

Corrado, Carol A., Jonathan Haskel, Massimiliano Iommi, and Cecilia Jona Lasinio. 2012. "Intangible Capital and Growth in Advanced Economies: Measurement and Comparative Results.” http://www.intan-invest.net/.

Corrado, Carol, Charles Hulten, and Daniel Sichel. 2009. "Intangible Capital and U.S. Economic Growth.” Review of Income \& Wealth 55 (3): 661-85.

Corrrado, Carol, and Kirsten Jager. 2015. "Wealth and Investment in Mature Societies.” In . Brussels, Belgium.

Decker, Ryan, John Haltiwanger, Ron Jarmin, and Javier Miranda. 2016. “The Decline of HighGrowth Entrepreneurship.” VoxEU.org. March 19. http://www.voxeu.org/article/declinehigh-growth-entrepreneurship.

Doms, Mark. 2005. “Communication Equipment: What Has Happened to Prices?” In Measuring Capital in the New Economy, edited by Carol Corrado, John Haltiwanger, and Daniel Sichel, 323-62. NBER Studies in Income and Wealth, vol. 65. 
Dulberger, Ellen R. 1989. “The Application of a Hedonic Model to a Quality-Adjusted Price Index for Computer Processors.” In Technology and Capital Formation, edited by Dale W. Jorgenson and Ralph Landau, 37-75. Cambridge, Mass. and London:

Eichengreen, Barry, Donghyun Park, and Kwanho Shin. 2015. “The Global Productivity Slump: Common and Country-Specific Factors.” doi:http://www.nber.org/papers/w21556.pdf.

Evans, David S., Richard Schmalensee, and Scott R. Murray. 2016. “The Census Bureau Needs to Significantly Revise Reporting and Calculation of Its Online and Physical Retail Sales Figures and Commission an Independent Review.” SSRN Scholarly Paper ID 2728918. Rochester, NY: Social Science Research Network. http://papers.ssrn.com/abstract=2728918.

Feenstra, Robert C., Benjamin R. Mandel, Marshall B. Reinsdorf, and Matthew J. Slaughter. 2013. "Effects of Terms of Trade Gains and Tariff Changes on the Measurement of US Productivity Growth.” American Economic Journal: Economic Policy 5 (1): 59-93. doi:http://www.aeaweb.org/aej-policy/.

Feldstein, Martin. 2015. “The U.S. Underestimates Growth.” Wall Street Journal, May 18, sec. Opinion.

Fernald, John. 2014a. “A Quarterly, Utilization-Adjusted Series on TFP.” Federal Reserve Bank of San Francisco.

_. 2014b. "Productivity and Potential Output Before, During, and after the Great Recession.” National Bureau of Economic Research.

Fernald, John G. 1999. "Roads to Prosperity? Assessing the Link between Public Capital and Productivity.” American Economic Review, 619-38.

Fernald, John G. and Marshall Reinsdorf. 2016. “Can We Bring Advertising-Supported Activity into Business-Sector Value Added?” Preliminary manuscript.

Flamm, Kenneth. 1989. "Technological Advance and Costs: Computers versus Communications.” In Changing the Rules: Technological Change, International Competition, and Regulation in Communications, edited by Robert W. Crandall and Kenneth Flamm, 13-61. Washington, D.C.:

Goolsbee, Austan, and Peter J. Klenow. 2006. "Valuing Consumer Products by the Time Spent Using Them: An Application to the Internet.” National Bureau of Economic Research. http://www.nber.org/papers/w11995.

Gordon, Robert J. 1990. The Measurement of Durable Goods Prices. Chicago: The University of Chicago Press.

—. 2015. "Productivity, Prices, and Measurement.” Stanford University.

- 2016. The Rise and Fall of American Growth: The U.S. Standard of Living since the Civil War. Princeton: Princeton University Press.

Greenstein, Shane, and Ryan C. McDevitt. 2009. "The Broadband Bonus: Accounting for Broadband Internet’s Impact on US GDP.” National Bureau of Economic Research. http://www.nber.org/papers/w14758.

Greenwood, Jeremy, Ananth Seshadri, and Mehmet Yorukoglu. 2005. "Engines of Liberation.” The Review of Economic Studies 72 (1): 109-33. 
Griliches, Zvi. 1994. "Productivity, R\&D, and the Data Constraint.” American Economic Review 84 (1): 1-23.

Grimm, Bruce T. 1996. A Quality-Adjusted Price Index for Digital Telephone Switches. . 1998. "Price Indexes for Selected Semiconductors, 1974-96.” Survey of Current Business 78 (2): 8-24.

Grimm, Bruce T., Brent R. Moulton, and David B. Wasshausen. 2005. “Information-Processing Equipment and Software in the National Accounts.” In , edited by Carol Corrado, John Haltiwanger, and Daniel Sichel. Measuring Capital in the New Economy. Chicago: The University of Chicago Press.

Grimm, Bruce T., and Robert Parker. 2000. "Recognition of Business and Government Expenditures for Software as Investment: Methodology and Quantitative Impacts, 195998.” http://www.bea.gov/about/pdf/software.pdf.

Hatzius, Jan, and Kris Dawsey. 2015. "Doing the Sums on Productivity Paradox v2.0.” Goldman Sachs U.S. Economics Analyst 15 (30).

Hausman, Jerry. 1999. “Cellular Telephone, New Products, and the CPI.” Journal of Business and Economic Statistics 17 (2): 188-94.

Heather, James M., and Benjamin Chain. “The Sequence of Sequencers: The History of Sequencing DNA.” Genomics 107, no. 1 (January 2016): 1-8.

Holdway, Michael. 2001. “Quality-Adjusting Computer Prices in the Producer Price Index: An Overview.” Bureau of Labor Statistics. http://data.bls.gov/cgibin/print.pl/ppi/ppicomqa.htm.

Houseman, Susan, Christopher Kurz, Paul Lengermann, and Benjamin Mandel. 2011. “Offshoring Bias in US Manufacturing.” The Journal of Economic Perspectives, 111-32.

Kim, Mina, and Marshall Reinsdorf. 2015. "The Impact of Globalization on Prices: A Test of Hedonic Price Indexes for Imports.” Upjohn Press Book Chapters, January.

Mackie, Christopher, Katharine G. Abraham, and others. 2004. Beyond the Market:: Designing Nonmarket Accounts for the United States. National Academies Press.

Mandel, Michael. 2009. “Growth: Why the Stats Are Misleading.” Business Week, June 3.

—. 2016. "Where Is Innovation Falling Short?: Using Labor Market Indicators to Map the Successful Innovation Frontier.” In The New Entrepreneurial Growth Agenda.

McCallum, John C. 2016. “Disk Drive Prices (1955-2015).” Accessed January 24. http://www.jcmit.com/diskprice.htm.

McGrattan, Ellen R., and Edward C. Prescott. 2012. "The Great Recession and Delayed Economic Recovery: A Labor Productivity Puzzle?” Government Policies and the Delayed Economic Recovery, 115-54.

Nakamura, Emi, and Jon Steinsson. 2012. “Lost in Transit: Product Replacement Bias and Pricing to Market.” American Economic Review 102 (7): 3277-3316.

Nakamura, Leonard I., and Rachel H. Soloveichik. 2015. “Valuing 'Free’ Media Across Countries in GDP.” SSRN Scholarly Paper ID 2631621. Rochester, NY: Social Science Research Network. 
National Academy of Science Committee on National Statistics. 2002. "Panel Report.”

NIPA Handbook: Concepts and Methods of the U.S. National Income and Product Accounts. 2014. Washington, DC: Bureau of Economic Analysis. http://bea.gov/national/pdf/allchapters.pdf.

Nordhaus, William D. 2002. "Productivity Growth and the New Economy.” Brookings Papers on Economic Activity, no. 2: 211-44.

- 2006. "Principles of National Accounting for Nonmarket Accounts." In A New Architecture for the US National Accounts, 143-60. University of Chicago Press.

Nordhaus, William D., and Edward C. Kokkelenberg. 1999. Nature's Numbers: Expanding the National Economic Accounts to Include the Environment. National Academies Press.

“Producer Prices.” 2016. In BLS Handbook of Methods. Bureau of Labor Statistics. Accessed January 24. http://www.bls.gov/opub/hom/pdf/homch14.pdf.

Reinsdorf, Marshall. 1993. "The Effect of Outlet Price Differentials on the U.S. Consumer Price Index.” In Price Measurements and Their Uses, edited by Murray F. Foss, Marilyn E. Manser, and Allan H. Young, 227-54. National Bureau of Economic Research Studies in Income and Wealth, vol. 57.

Reinsdorf, Marshall, and Robert Yuskavage. 2014. “Offshoring, Sourcing Substitution Bias and the Measurement of US Import Prices, Real GDP and Productivity.” Bureau of Economic Analysis. https://ideas.repec.org/p/bea/wpaper/0109.html.

Schreyer, Paul, and W. Erwin Diewert. 2014. "Household Production, Leisure and Living Standards.” Measuring Economic Sustainability and Progress. National Bureau of Economic Research, NBER Studies in Income and Wealth, 89-114.

Shapiro, Matthew D., and David W. Wilcox. 1996. "Mismeasurement in the Consumer Price Index: An Evaluation.” In , edited by Ben S. Bernanke and Julio J. Rotemberg. NBER Macroeconomics Annual 1996. Cambridge, Mass.: MIT Press.

Sichel, Daniel E. 1997. “The Productivity Slowdown: Is a Growing Unmeasurable Sector the Culprit?” Review of Economics and Statistics 79 (3): 367-70.

Soloveichik, Rachel. 2015a. "Valuing 'Free’ Entertainment in GDP: An Experimental Approach.” Accessed April 1, 2016.

http://bea.gov/about/pdf/acm/2015/november/valuing-free-entertainment-in-gdp-for-aeapaper.pdf.

Soloveichik, Rachel. 2015b. “Exploring the Boundaries of GDP.” Accessed April 1, 2016. https://bea.gov/about/pdf/acm/2015/november/exploring-the-boundaries-of-gdp.pdf .

Stallman, Richard. 2016. “The GNU Manifesto.” Accessed March 2. http://www.gnu.org/gnu/manifesto.en.html.

Stein, Lincoln D. “The Case for Cloud Computing in Genome Informatics.” Genome Biol 11, no. 5 (2010). http://www.biomedcentral.com/content/pdf/gb-2010-11-5-207.pdf.

Syverson, Chad. 2016. "Challenges to Mismeasurement Explanations for the U.S. Productivity Slowdown.” Working Paper 21974. National Bureau of Economic Research. http://www.nber.org/papers/w21974. 
Triplett, Jack. 1990. "Prices and Technological Change in a Capital Good: A Survey of Research on Computers.” In , edited by Dale W. Jorgenson. Technology and Capital Formation. Cambridge, Mass.+: MIT Press.

Triplett, Jack E. 1982. “Concepts of Quality in Input and Output Price Measures: A Resolution of the User-Value Resource-Cost Debate.” NBER, January, 269-312.

- 1999. "Economic Statistics, the New Economy, and the Productivity Slowdown.” Business Economics 34 (2): 13-17. doi:http://www.palgravejournals.com/be/archive/index.html.

Triplett, Jack E., and Barry Bosworth. 2004. Productivity in the US Services Sector: New Sources of Economic Growth. Brookings Institution Press.

United Nations. 2009. System of National Accounts 2008. European Commission, International Monetary Fund, Organisation for Economic Co-operation and Development, United Nations and World Bank, New York, Dec. 2009.

Varian, Hal. 2011. “The Economic Value of Google.” Presentation downloaded from http://cdn.oreillystatic.com/en/assets/1/event/57/The\%20Economic\%20Impact\%20of\%20 Google\%20Presentation.pdf (accessed April 6, 2016)

Wasshausen, David, and Brent R. Moulton. 2006. "The Role of Hedonic Methods in Measuring Real GDP in the United States.” Bureau of Economic Analysis.

Wetterstrand, KA. "DNA Sequencing Costs: Data from the NHGRI Genome Sequencing Program (GSP).” Accessed April 18, 2016. https://www.genome.gov/27541954/dnasequencing-costs/.

Zheng, Simon and Harry Bloch. 2014. "Australia’s Mining Productivity Decline: Implications for MFP Measurement," Journal of Productivity Analysis, Springer, vol. 41(2), pages 201-212, April. 
Figure 1: Published and adjusted U.S. labor productivity

\section{Adjustments to growth in output per hour}

Business sector, percentage points per year

Percentage points

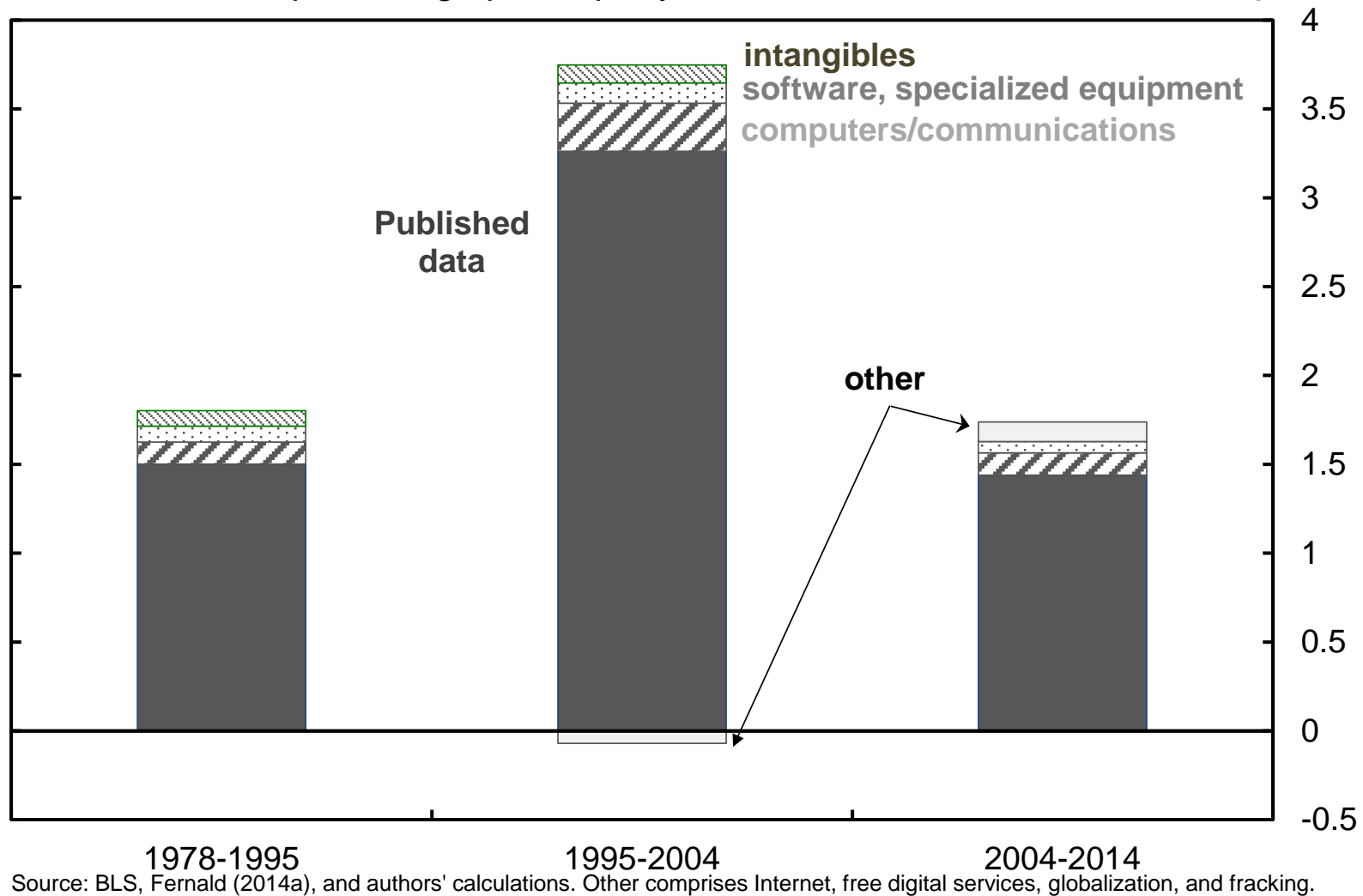


Figure 2: Contribution to U.S. TFP growth by industry subgroup

\section{U.S. total factor productivity by industry subgroup}

Contribution, annual percentage points

Percentage points

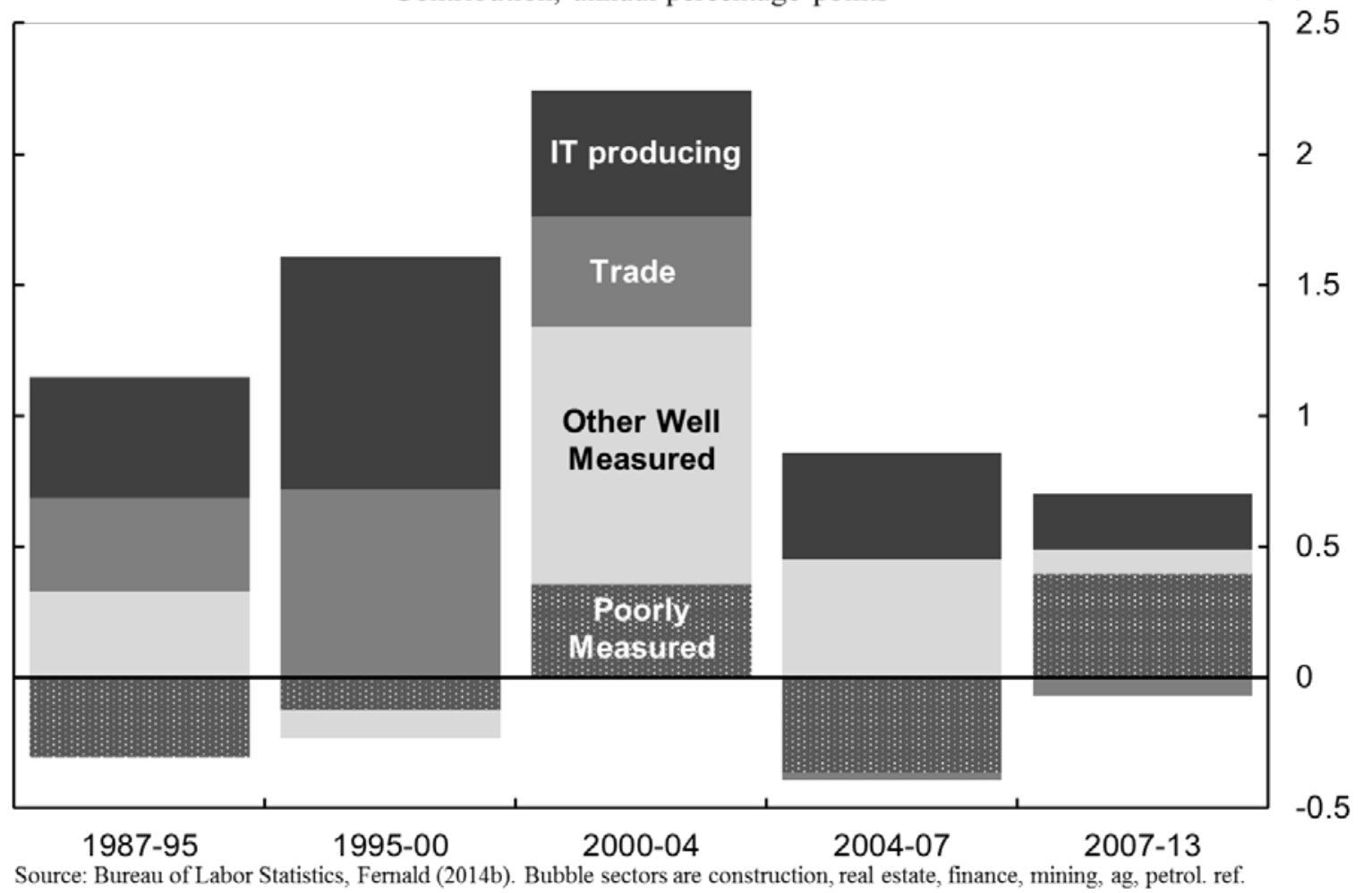

Notes: Aggregate TFP growth based on BLS industry data is decomposed into four mutually exclusive categories as shown. IT production is computer and electronic product manufacturing; publishing (including software); and computer systems design. Trade is wholesale and retail trade. "Other well measured” follows Nordhaus (2002), and comprises manufacturing (excluding IT producing), agriculture, mining, transportation, utilities, broadcasting, and accommodations. Remaining industries are in "poorly measured." See Fernald (2014b) for further details. Source: BLS and authors’ calculations. 


\section{Figure 3A: Aggregate TFP holding industry weights fixed}

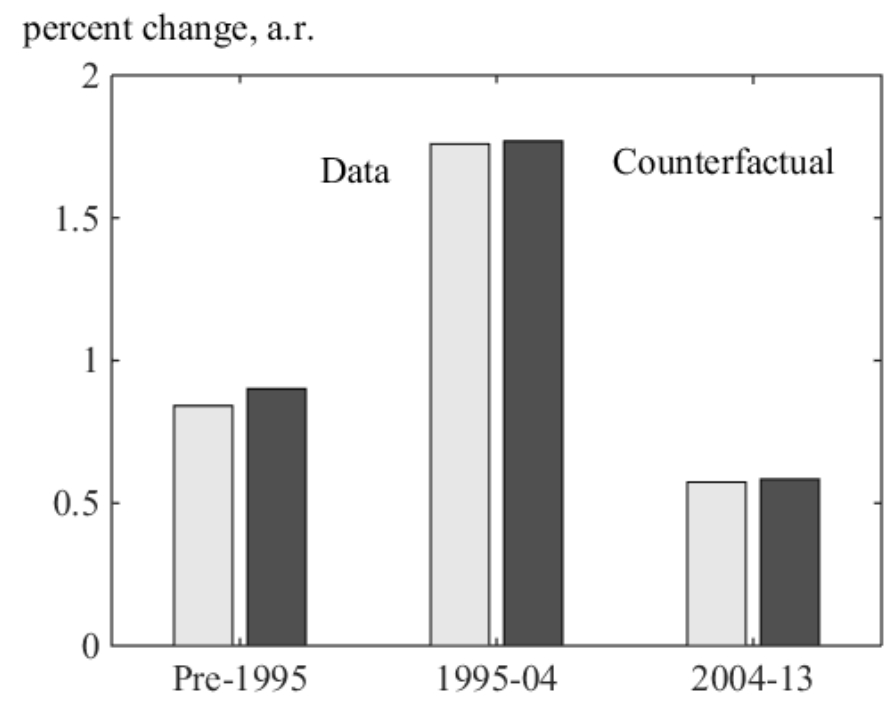

Note: Light bars show actual average growth in business-sector TFP over periods shown. Dark bars show counterfactual where nominal industry value-added weights (which multiply actual valueadded industry TFP growth) remain fixed at 1987 values. Source: BLS and authors' calculation.

\section{Panel B: Broadbased deceleration in TFP growth}

Notes: Horizontal axes ranks business-sector industries by the change in value-added TFP growth after 2004, i.e., average growth 2004-13 less average growth 1995-04. Growth rates calculated as 100 times log change. The three industries with the largest (positive) acceleration in TFP growth are (i) funds and trusts, (ii) water transport, and (iii) oil and gas mining. 
Figure 4: Prices for Information Technology

\section{Information technology investment prices}

3-year average changes in annual data

Percent

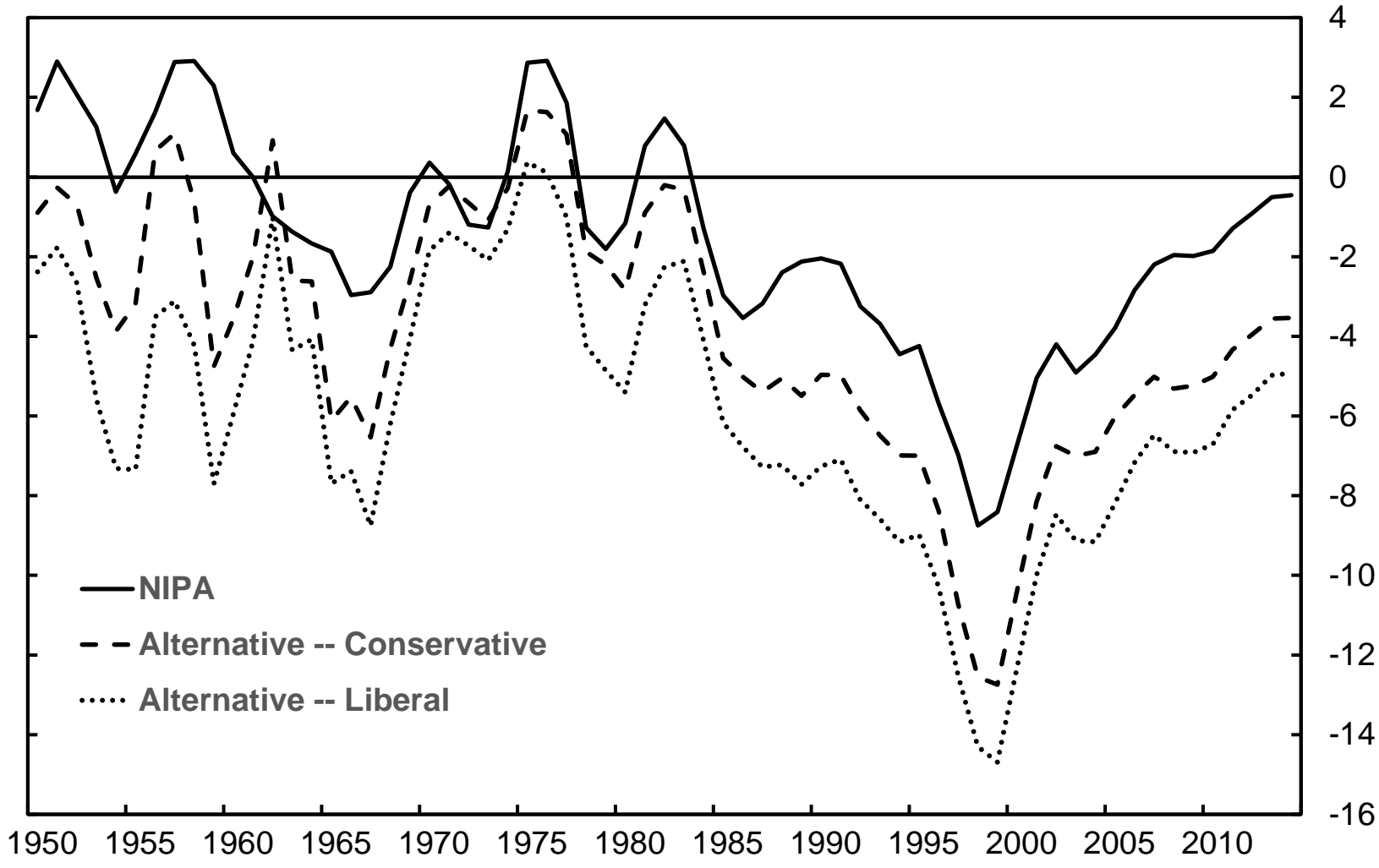

Source: Authors’ calculations. Percent calculated as 100 times log change. 
Figure 5: Prices for Personal Computers

\section{Panel A: Implicit Quality Adjustment}

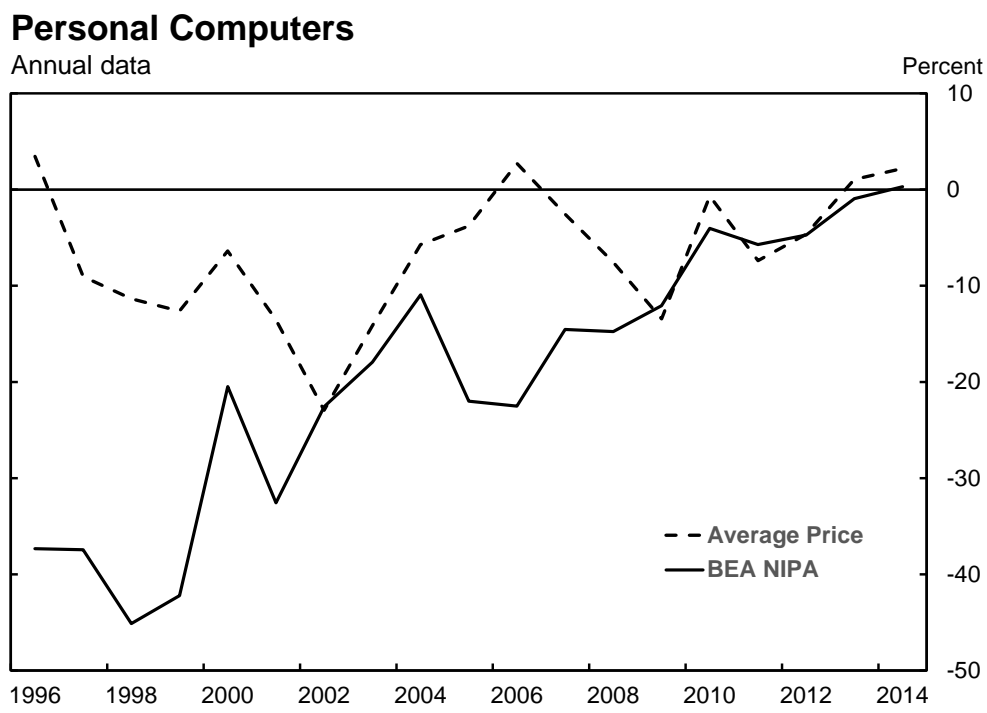

\section{Panel B: Domestic (PPI) and Imported Prices for PCs}

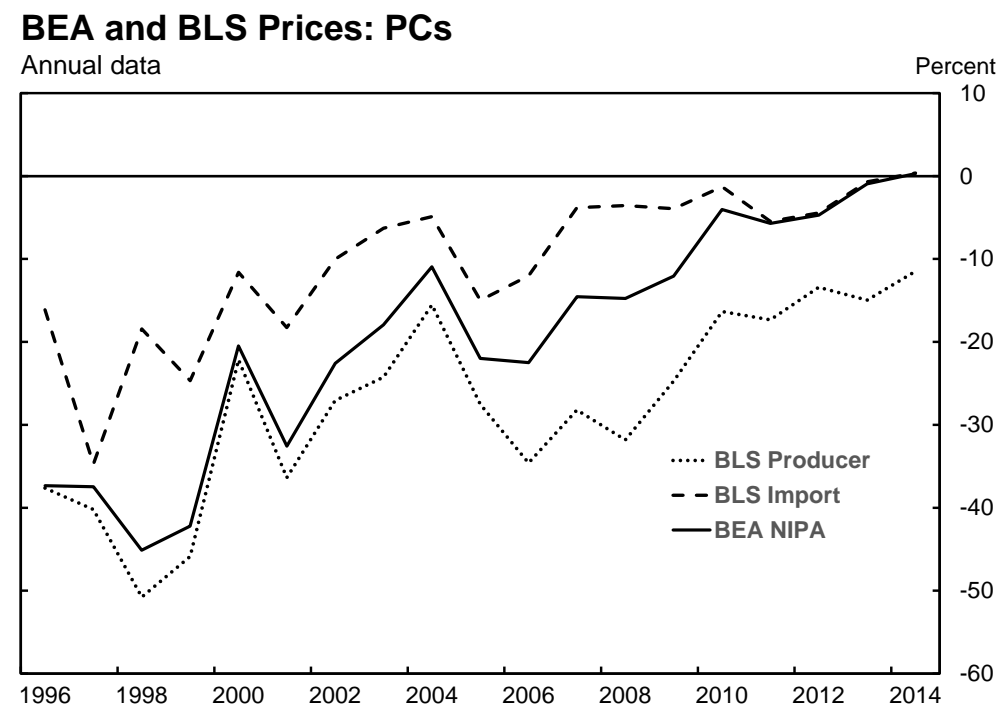

Source: Authors' calculations. Percent calculated as 100 times log change. 
Figure 6: Official and alternative computer and communications prices Computer and peripheral prices

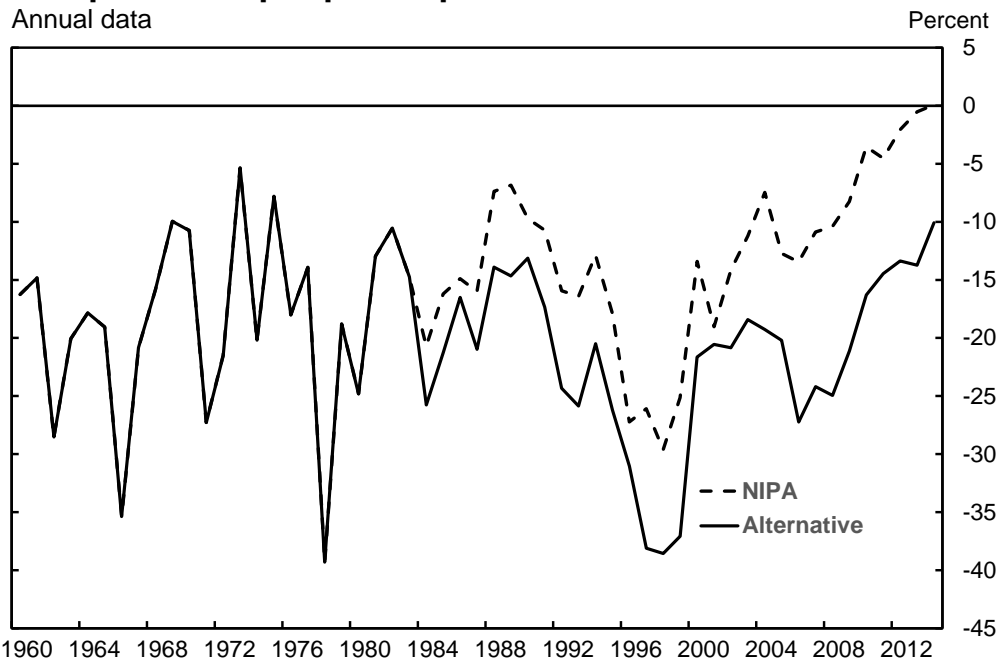

\section{Communications equipment prices}

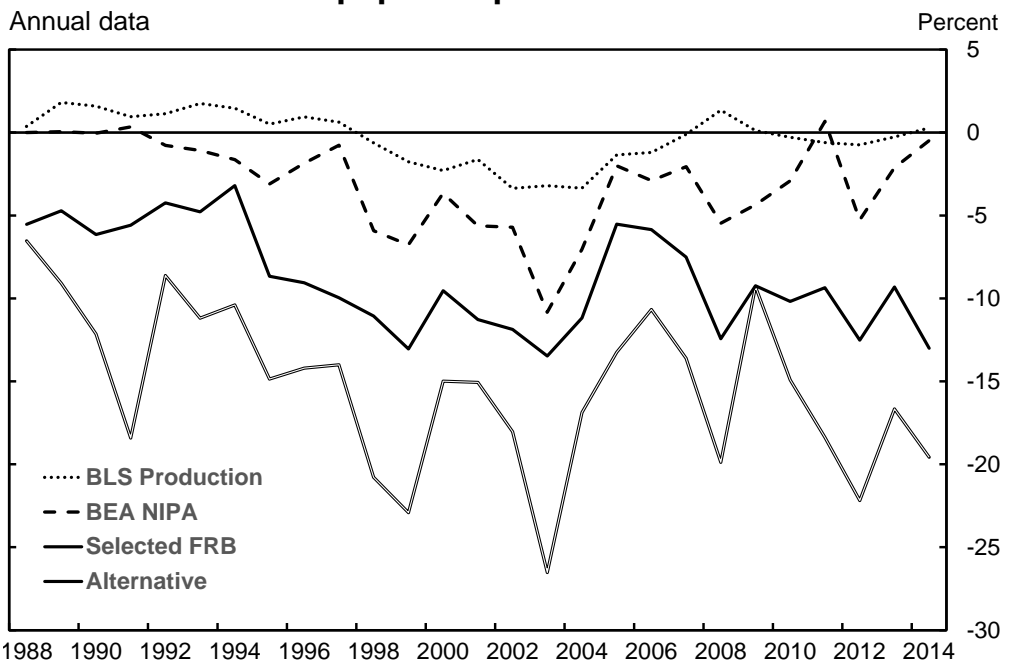

Source: Authors' calculations. Percent calculated as 100 times log change. 
Figure 7: U.S. production of oil and gas

\section{US production of oil and gas}

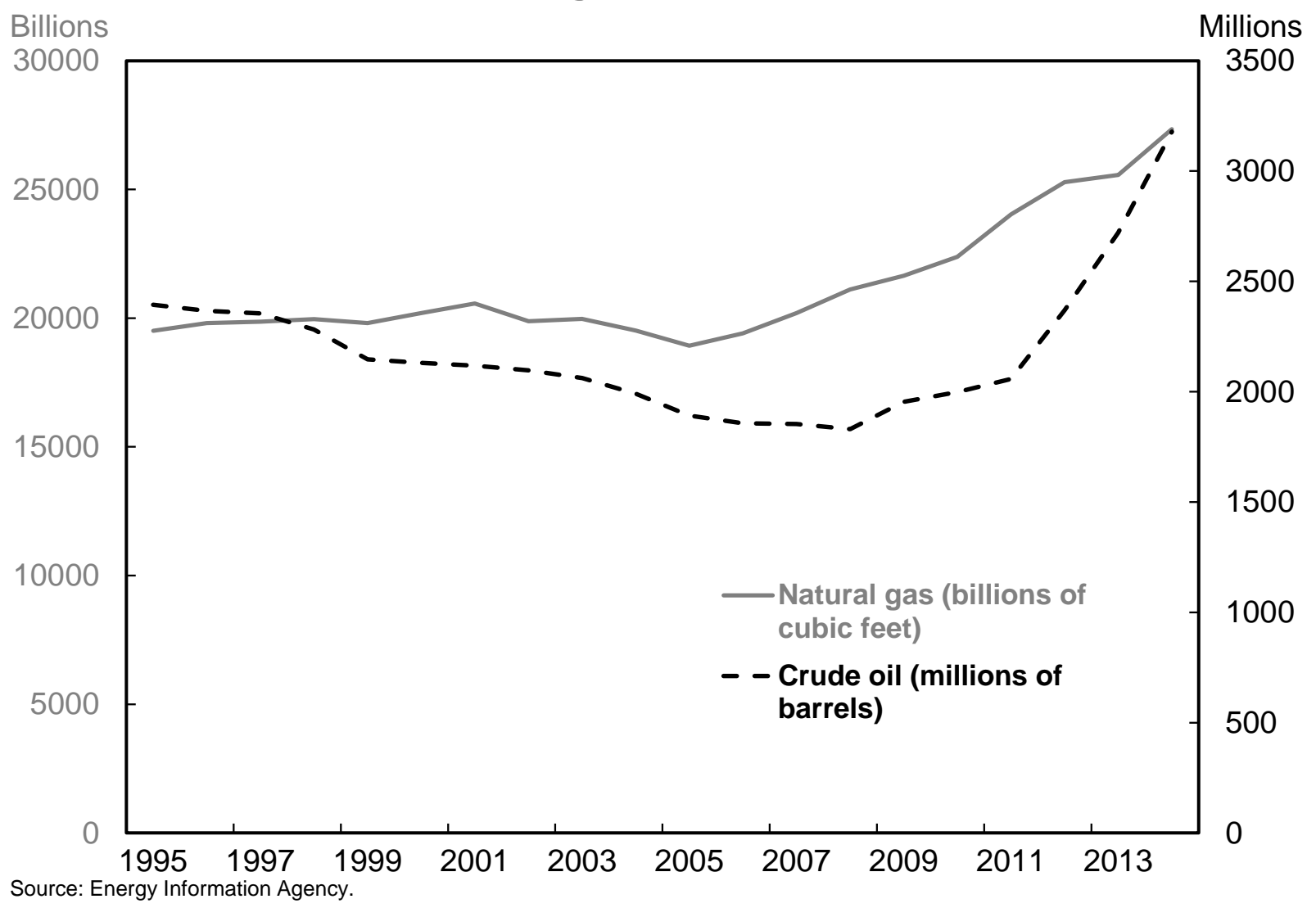


Table 1: Prices and weights for IT investment

\begin{tabular}{|c|c|c|c|c|}
\hline & \multicolumn{4}{|c|}{ Average } \\
\hline & 1947-1978 & 1978-1995 & $1995-2004$ & 2004-2014 \\
\hline IT Investment Share of BFI & $12 \%$ & $24 \%$ & $31 \%$ & $29 \%$ \\
\hline \multicolumn{5}{|l|}{ IT Investment Price Indexes } \\
\hline BEA NIPA & $0.2 \%$ & $-2.2 \%$ & $-6.1 \%$ & $-1.4 \%$ \\
\hline Alternative -- Conservative & $-1.8 \%$ & $-4.4 \%$ & $-9.2 \%$ & $-4.4 \%$ \\
\hline Alternative -- Liberal & $-3.9 \%$ & $-6.5 \%$ & $-11.2 \%$ & $-5.9 \%$ \\
\hline \multicolumn{5}{|l|}{ Share of IT Investment } \\
\hline Computers and Peripherals & $13.1 \%$ & $22.8 \%$ & $20.8 \%$ & $14.5 \%$ \\
\hline Communications Equipment & $36.9 \%$ & $26.6 \%$ & $22.6 \%$ & $17.0 \%$ \\
\hline Other Info. Systems Equipment & $38.3 \%$ & $26.7 \%$ & $17.3 \%$ & $20.4 \%$ \\
\hline Software & $11.7 \%$ & $23.9 \%$ & $39.3 \%$ & $48.2 \%$ \\
\hline \multicolumn{5}{|l|}{ Price Deflators } \\
\hline \multicolumn{5}{|l|}{ Computers and Peripherals* } \\
\hline BEA NIPA & $-18.1 \%$ & $-14.6 \%$ & $-19.3 \%$ & $-6.6 \%$ \\
\hline Alternative & $-18.1 \%$ & $-19.0 \%$ & $-27.3 \%$ & $-18.6 \%$ \\
\hline \multicolumn{5}{|l|}{ Communications Equipment } \\
\hline BEA NIPA & $1.9 \%$ & $1.4 \%$ & $-5.4 \%$ & $-2.7 \%$ \\
\hline Alternative & $-3.0 \%$ & $-2.7 \%$ & $-11.2 \%$ & $-10.3 \%$ \\
\hline \multicolumn{5}{|l|}{ Other Info. Systems Equipment } \\
\hline BEA NIPA & $2.3 \%$ & $2.9 \%$ & $-0.6 \%$ & $0.5 \%$ \\
\hline Alternative & $-1.7 \%$ & $-2.2 \%$ & $-8.9 \%$ & $-4.9 \%$ \\
\hline \multicolumn{5}{|l|}{ Software* } \\
\hline BEA NIPA & $-0.7 \%$ & $-1.2 \%$ & $-1.1 \%$ & $0.1 \%$ \\
\hline Alternative & $-4.8 \%$ & $-4.4 \%$ & $-2.5 \%$ & $-0.8 \%$ \\
\hline \multicolumn{5}{|c|}{ Note. "Conservative" alternative incorporates alternative computer and communications } \\
\hline \multicolumn{5}{|c|}{ prices. "Liberal" alternative adds alternative software and special-purpose prices. } \\
\hline \multicolumn{5}{|c|}{\begin{tabular}{|l|l|l|} 
Computers and software price indexes begin in 1958. & \\
\end{tabular}} \\
\hline
\end{tabular}


Table 2: Adjustments to business-sector growth-accounting

(percentage points per year relative to baseline)

\begin{tabular}{|c|c|c|c|c|c|}
\hline & & & annual pp. c & change rela & e to baseline \\
\hline & & $(0)$ & $(1)$ & $(2)$ & (3) \\
\hline & & $\begin{array}{l}\text { Published baseline } \\
\text { (\% change, a.r.) }\end{array}$ & Conservative & Liberal & $\begin{array}{l}\text { Liberal + } \\
\text { Intangibles }\end{array}$ \\
\hline Labor productivity & 1978-1995 & 1.50 & 0.12 & 0.21 & 0.30 \\
\hline & $1995-2004$ & 3.26 & 0.27 & 0.38 & 0.49 \\
\hline & 2004-2014 & 1.44 & 0.13 & 0.19 & 0.18 \\
\hline & 2004-2010 & 1.92 & 0.17 & 0.25 & 0.24 \\
\hline & $2010-2014$ & 0.71 & 0.06 & 0.11 & 0.10 \\
\hline Capital-hours ratio & 1978-1995 & 2.20 & 0.27 & 0.52 & 0.66 \\
\hline & $1995-2004$ & 3.68 & 0.54 & 0.89 & 1.02 \\
\hline & 2004-2014 & 1.80 & 0.44 & 0.70 & 0.55 \\
\hline & 2004-2010 & 3.14 & 0.46 & 0.74 & 0.54 \\
\hline & $2010-2014$ & -0.22 & 0.41 & 0.63 & 0.58 \\
\hline TFP & 1978-1995 & 0.53 & 0.04 & 0.05 & -0.01 \\
\hline & $1995-2004$ & 1.82 & 0.09 & 0.09 & -0.08 \\
\hline & 2004-2014 & 0.49 & -0.04 & -0.07 & -0.12 \\
\hline & 2004-2010 & 0.44 & 0.00 & -0.02 & -0.12 \\
\hline & $2010-2014$ & 0.58 & -0.10 & -0.14 & -0.12 \\
\hline$(0)=$ Baseline, $\mathrm{bu}$ & ess sector, from I & 'ernald (2014a) & & & \\
\hline$(1)=$ Alt. deflator & r computers and & communications ("cor & rvative") & & \\
\hline$(2)=(1)+$ alt. def & rs for specialize & equipment and softy & e ("liberal") & & \\
\hline$(3)=(2)+$ intangi & $\mathrm{s}$ from Corrado e & al (2012, updated) & & & \\
\hline Note: Averages star & 78 because of av & ailability of intangib & & & \\
\hline
\end{tabular}

Notes: Column (1) to (3) each involve a separate, experimental adjustment to selected components of capital investment. The entries show the percentage-point adjustment to businesssector growth accounting components, relative to the unadjusted estimates in column (0). 